\title{
Leren loont! : de overgang van school naar werk voor leerlingen van het VOCL ' 89
}

Citation for published version (APA):

Traag, T., van der Valk, J., van der Velden, R. K. W., de Vries, M. R., \& Wolbers, M. H. J. (2004). Leren loont! : de overgang van school naar werk voor leerlingen van het VOCL '89. Researchcentrum voor Onderwijs en Arbeidsmarkt, Faculteit der Economische Wetenschappen. ROA Reports No. 6 https://doi.org/10.26481/umarep.2004006

Document status and date:

Published: 01/01/2004

DOI:

10.26481/umarep.2004006

Document Version:

Publisher's PDF, also known as Version of record

\section{Please check the document version of this publication:}

- A submitted manuscript is the version of the article upon submission and before peer-review. There can be important differences between the submitted version and the official published version of record.

People interested in the research are advised to contact the author for the final version of the publication, or visit the DOI to the publisher's website.

- The final author version and the galley proof are versions of the publication after peer review.

- The final published version features the final layout of the paper including the volume, issue and page numbers.

Link to publication

\footnotetext{
General rights rights.

- You may freely distribute the URL identifying the publication in the public portal. please follow below link for the End User Agreement:

www.umlib.nl/taverne-license

Take down policy

If you believe that this document breaches copyright please contact us at:

repository@maastrichtuniversity.nl

providing details and we will investigate your claim.
}

Copyright and moral rights for the publications made accessible in the public portal are retained by the authors and/or other copyright owners and it is a condition of accessing publications that users recognise and abide by the legal requirements associated with these

- Users may download and print one copy of any publication from the public portal for the purpose of private study or research.

- You may not further distribute the material or use it for any profit-making activity or commercial gain

If the publication is distributed under the terms of Article $25 \mathrm{fa}$ of the Dutch Copyright Act, indicated by the "Taverne" license above, 


\title{
Leren loont! \\ De overgang van school naar werk voor leerlingen van het VOCL'89
}

ROA-R-2004/6

\author{
Tanja Traag (CBS) \\ Johan van der Valk (CBS) \\ Rolf van der Velden (ROA) \\ Robert de Vries (ROA) \\ Maarten Wolbers (ROA)
}

\section{Researchcentrum voor Onderwijs en Arbeidsmarkt \\ Faculteit der Economische Wetenschappen en Bedrijfskunde Universiteit Maastricht}

Maastricht, augustus 2004 


\section{医}

들 Centraal Bureau voor de Statistiek

$\underset{1}{1}$

Researchcentrum voor Onderwijs en Arbeidsmarkt

Research Centre for Education and the Labour Market 


\section{Inhoud}

Bladzijde

Voorwoord

1 Inleiding 1

1.1 Aanleiding 1

1.2 Doelstelling 4

1.3 Probleemstelling 4

1.4 Opzet van dit rapport 5

2 Datamateriaal 7

2.1 Consequenties van paneldesigns 8

2.2 Variabelen en operationalisaties 9

3 Beschrijvende analyses 13

3.1 De conjunctuurgevoeligheid van arbeidsmarktkenmerken 13

3.2 Werkloosheid en vast werk 14

3.3 De aansluiting tussen de opleiding en de baan 16

$\begin{array}{ll}3.4 & \text { Loon en beroepsprestige } \\ & 18\end{array}$

4 Verklarende analyses $\quad 21$

4.1 Bereikt opleidingsniveau 21

4.2 Werkzame beroepsbevolking 24

4.3 Vast werk 26

$\begin{array}{lll}4.4 & \text { Baan naar niveau en richting } & 27\end{array}$

$\begin{array}{lll}4.5 & \text { Beroepsprestige } & 30\end{array}$

$\begin{array}{lll}4.6 & \text { Persoonlijk bruto jaarloon } & 33\end{array}$

5 Samenvatting en conclusies $\quad 37$

$\begin{array}{ll}5.1 \text { Samenvatting } & 37\end{array}$

$\begin{array}{ll}5.2 \text { Conclusies } & 39\end{array}$

$\begin{array}{ll}\text { Bijlage } 1 \text { Populatie } & 41\end{array}$

Bijlage 2 Het corrigeren van leeftijd-, periode- en cohorteffecten 43

Bijlage 3 Operationalisering van de variabelen $\quad 45$

$\begin{array}{ll}\text { Literatuur } & 49\end{array}$ 



\section{Voorwoord}

De overgang van school naar werk is vanuit zowel onderwijs- als werkgelegenheidsbeleid een zeer belangrijke fase. Onderwijs bepaalt in belangrijke mate de latere levenskansen in het algemeen en de arbeidsmarktkansen in het bijzonder. Zowel op nationaal als ook in EU-verband worden daarom maatregelen genomen om de stap naar de arbeidsmarkt zo succesvol mogelijk te maken. Hiervoor is echter meer inzicht nodig in de betekenis van het onderwijs voor een succesvolle start op de arbeidsmarkt. Eind jaren ' 80 en begin jaren '90 was de arbeidsmarktsituatie voor jongeren weinig rooskleurig. Dit uitte zich vooral in een hoge mate van jeugdwerkloosheid. Dit heeft ertoe geleid dat men vanuit het beleid de overgang van school naar werk beter inzichtelijk heeft willen maken. In dit rapport staat de vraag centraal in welke mate het onderwijs bepalend is voor de mate waarin men succesvol toetreedt tot de arbeidsmarkt en welke factoren die al aanwezig waren voordat men startte in het onderwijs, de arbeidsmarktkansen beïnvloeden. Hierbij worden cognitieve kenmerken, soft skills en ouderlijke hulpbronnen onderscheiden.

Om deze onderzoeksvragen te beantwoorden heeft het Centraal Bureau voor de Statistiek (CBS) het Voortgezet Onderwijs Cohort Leerlingen 1989 (VOCL'89) gekoppeld aan zowel schoolverlatersgegevens (SVD 1994-2002) als loongegevens uit het Regionaal Inkomens Onderzoek (RIO 1995-2000). Het bestand met schoolverlatersgegevens is een bron die pas sinds kort is ontsloten voor analyse, bovendien is dit een van de weinige bronnen die longitudinale informatie bevat over zowel de onderwijs- als de arbeidsmarktloopbaan. De analyses in dit rapport zijn de eerste onderzoeksresultaten die gebaseerd zijn op deze dataset.

Deze studie laat zien dat het onderwijsniveau de belangrijkste verklarende factor is voor arbeidsmarktsucces. Naarmate men hoger is opgeleid blijken de kansen op de arbeidsmarkt toe te nemen. Dit uit zich met name in een kleinere werkloosheidskans, meer prestigieuze banen en een hoger inkomen. Het behaalde onderwijsniveau blijkt bepaald te worden door zowel cognitieve kenmerken als soft skills en ouderlijke hulpbronnen. Hierbij blijkt het schooladvies dat is afgegeven in groep 8 van het basisonderwijs de belangrijkste factor te zijn, gevolgd door schoolprestaties, prestatiemotivatie, schoolbeleving en vervolgens non-verbale intelligentie. Van de sociale en culturele hulpbronnen blijkt het opleidingsniveau van de ouders het meest belangrijk te zijn, gevolgd door de maatschappelijke positie, het onderwijsondersteunend klimaat en de culturele participatie. Non-verbale intelligentie en de maatschappelijke positie van de ouders hebben niet alleen indirect, via het behaalde opleidingsniveau, maar ook direct een positieve invloed op de kans op betaald werk. Daarentegen is er geen directe invloed van schoolprestaties en schoolbeleving, prestatiemotivatie en de overige sociale en culturele hulpbronnen op de kans op betaald werk. Maatschappelijke positie van de ouders en onderwijsondersteunend thuisklimaat hebben ook een direct effect op de kans om vast werk te krijgen, terwijl van de culturele participatie van de ouders gek genoeg een negatief effect uitgaat. Verder hebben schooladvies, schoolprestaties, schoolbeleving en opleidingsniveau 
van de ouders, los van het behaalde opleidingsniveau, een positieve invloed op het prestige van de baan van schoolverlaters.

Dit rapport is het resultaat van een strategisch samenwerkingsverband tussen CBS en ROA. Deze samenwerking is in het najaar van 2003 gestart en beoogt inzicht te geven in de transitie van het onderwijs naar de arbeidsmarkt. De aandacht voor transities op, van en naar de arbeidsmarkt is het kernpunt van het 'Strategisch Programma Sociale Dynamiek en Arbeidsmarkt van het CBS. Als inhoudelijke toespitsing van de samenwerking tussen CBS en ROA is gekozen voor het thema 'de transitie van school naar werk': hoe verloopt de stap van het onderwijs naar de arbeidsmarkt op korte en lange termijn? Gelet op de eerste resultaten van de samenwerking tussen het CBS en het ROA hebben wij besloten om deze perspectiefvolle samenwerking voort te zetten.

Prof. dr. Hans Heijke

Directeur ROA
Prof. dr. Jarig van Sinderen plv. Directeur-generaal CBS 


\section{$1 \quad$ Inleiding}

Om de kwaliteitsverbetering en vernieuwing van het CBS-programma een impuls te geven, zal in de komende jaren een omvangrijk programma van strategisch onderzoek worden uitgevoerd. Het CBS maakt statistieken over vrijwel alle aspecten van de samenleving. De ontwikkeling, analyse en presentatie van de informatie in de juiste context vereist een grondige kennis van die context. Daarom heeft het CBS behoefte aan diepgaande kennis op een zeer breed terrein. Dat geldt zeker voor nieuwe maatschappelijke ontwikkelingen, maar ook voor ontwikkelingen op technologisch en methodologisch gebied. In de keuze van de onderwerpen van strategisch onderzoek wordt een forse bijdrage aan kennisontwikkeling weerspiegeld, wat past in het streven om het CBS te transformeren tot een kennisinstituut van hoge nationale en internationale allure.

Een van de thema's die binnen het strategisch onderzoek verder uitgediept zullen worden is het thema Sociale Dynamiek en Arbeidsmarkt. ${ }^{1}$ Aanleiding voor dit thema is in de eerste plaats de behoefte aan statistische informatie als gevolg van de toegenomen sociale dynamiek en pluriformiteit in de samenleving. Ten tweede is er steeds meer behoefte aan stroominformatie ter evaluatie van beleid gericht op bevordering van instroom in de arbeidsmarkt en ter belemmering van uitstroom uit de arbeidsmarkt. Daarnaast hebben ook grootschalige veranderingen in arbeidsaanbod en het leven van mensen geleid tot een grotere behoefte aan een dynamisch integratiekader waarin zowel de sociale dynamiek als de dynamiek op de arbeidsmarkt aan elkaar gerelateerd worden.

In het kader van het strategisch onderzoek Sociale Dynamiek en Arbeidsmarkt zijn het CBS en het Researchcentrum voor Onderwijs en Arbeidsmarkt (ROA) een gezamenlijk onderzoek gestart naar de transitie van het onderwijs naar de arbeidsmarkt. Dit gezamenlijke onderzoek bestaat uit een drietal deelprojecten:

1. Een onderzoek naar de korte termijn effecten van het onderwijs: transities en competenties

2. Een onderzoek naar de lange termijn effecten van het onderwijs

3. Versterking van de data infrastructuur.

In dit rapport wordt verslag gedaan van de resultaten uit het eerste deelproject.

\subsection{Aanleiding}

De beleidsrelevantie van informatie over de overgang van school naar werk is hoog. Het is een zeer belangrijke fase zowel voor het werkgelegenheidsbeleid als onderwijsbeleid.

1. Dit gezamenlijke ROA-CBS onderzoek valt binnen het strategisch onderzoeksprogramma Sociale dynamiek en arbeidsmarkt van het CBS, een programma dat samen met andere kennisinstituten statistische informatie op het terrein van arbeidsmarkt-, inkomens- en huishoudensdynamiek ontwikkelt.

Voor meer informatie: http://www.cbs.nl/nl/service/onderzoek/strat-ondz/index.htm. 
1. Schoolverlaters en jongeren zijn kwetsbare groepen op de arbeidsmarkt. Zowel nationaal als in EU-verband worden maatregelen genomen om er voor te zorgen dat zij succesvol instromen op de arbeidsmarkt. Onderwijs bepaalt in belangrijke mate de latere levenskansen in het algemeen en de arbeidsmarktkansen in het bijzonder (Dronkers \& Ultee, 1995). Bij de transitie van school naar werk worden de eerste opbrengsten van het gevolgde onderwijs zichtbaar. Inzicht in dit transitie proces werpt licht op de betekenis van onderwijs in het allocatieproces.

2. Schoolverlaters zijn zeer gewild op de arbeidsmarkt. Zij zijn flexibel, dynamisch en regionaal ongebonden. Het is echter wel van belang dat zij adequaat toegerust zijn. Dat betekent goed opgeleid en in het bezit van de juiste vaardigheden.

3. In de laatste decennia heeft het transitieproces meer en meer trekken gekregen van een 'chaotisch' verlopend proces (Hannan \& Werquin, 1999). De jaren '80 en de eerste helft van de jaren '90 werden gekenmerkt door een 'precaire' arbeidsmarktsituatie voor jongeren, onder andere tot uitdrukking komend in een hoge jeugdwerkloosheid in vrijwel alle West-Europese landen (Ryan \& Büchtemann, 1996). Vanuit het beleid werd daarom de behoefte gevoeld om deze overgang meer systematisch te monitoren. De grote arbeidsmarktdynamiek onder jongeren wordt mede veroorzaakt door het uitvoeren van vakantiewerk of het hebben van bijbaantjes. Daardoor is in de werkgelegenheid en de werkloosheid onder jongeren een groot seizoenpatroon zichtbaar. Om de invloed van de conjunctuur op de arbeidsmarktsituatie van jongeren goed te kunnen beoordelen is het zeer belangrijk de verschillende categorieën werkende en werkzoekende jongeren afzonderlijk te kunnen onderscheiden, zodanig dat een onderscheid gemaakt kan worden tussen jongeren met bijbanen en jongeren die de stap van het onderwijs naar de arbeidsmarkt hebben gemaakt.

4. Op de verschillende niveaus van het onderwijs worden indicatoren ontwikkeld om de kwaliteit van het onderwijs te beschrijven: op het niveau van landen (OECD, 1998), op het niveau van opleidingen (ROA, 1999) en op het niveau van onderwijsinstellingen (Dronkers, 1998). Hierbij is een toenemende aandacht voor het meten van de externe effecten en de opbrengsten van het onderwijs (Van der Velden, 2001).

Het overgangsproces van school naar werk kan globaal in drie fases verdeeld worden. De eerste fase wordt gevormd door de schoolloopbaan, de periode van het initieel onderwijs. De tweede fase bestaat uit het zoeken naar werk en het vinden van een baan, direct na het verlaten van de laatste opleiding van het initieel onderwijs. De derde fase is de verdere arbeidsloopbaan. Deze fasering is schematisch weergegeven in figuur 1.1. Er is statistische informatie nodig over alle fases en de relaties tussen de afzonderlijke fases. Welke invloed heeft de schoolloopbaan op het zoeken of vinden van werk? Welke invloed heeft de opleiding op het vinden van werk?

Zoals blijkt uit figuur 1.1 is de transitie van school naar werk een complex geheel, waarvan nog niet duidelijk is hoe de afzonderlijke fases er precies uitzien en hoe ze onderling samenhangen. Het beschikbaar zijn van verschillende, complementaire databronnen maakt dat we met een redelijke mate van precisie de kortetermijn 
opbrengsten van het onderwijs kunnen vaststellen. Daarmee zijn we er echter nog niet. Het is belangrijk om het perspectief van waaruit dit transitieproces bestudeerd wordt, te verbreden naar competenties en loopbanen. Immers, vaststellen dat opleidingen onderscheiden startkansen geven op de arbeidsmarkt geeft nog geen inzicht in de vraag wat het onderwijs hiertoe bijgedragen heeft. In het arbeidssociologische en -economische onderzoek wordt het onderwijs in de regel beschouwd als een 'black box'. Het in het onderwijs vergaarde menselijk kapitaal wordt daarbij meestal unidimensioneel gemeten op basis van de output van het onderwijs (bijv. het aantal jaren gevolgd onderwijs). Om de betekenis van het onderwijs voor het selectie- en allocatieproces op de arbeidsmarkt te kunnen doorgronden is het nodig om deze black box te openen en na te gaan welke kennis en vaardigheden schuil gaan achter de etiketten van de verschillende diploma's. De hiervoor noodzakelijke analyses zullen worden uitgevoerd in deelproject 1 en worden beschreven in dit rapport. De langetermijn effecten van het onderwijs zullen in een volgend project onderzocht worden.

Figuur 1.1

De transitie van school naar werk

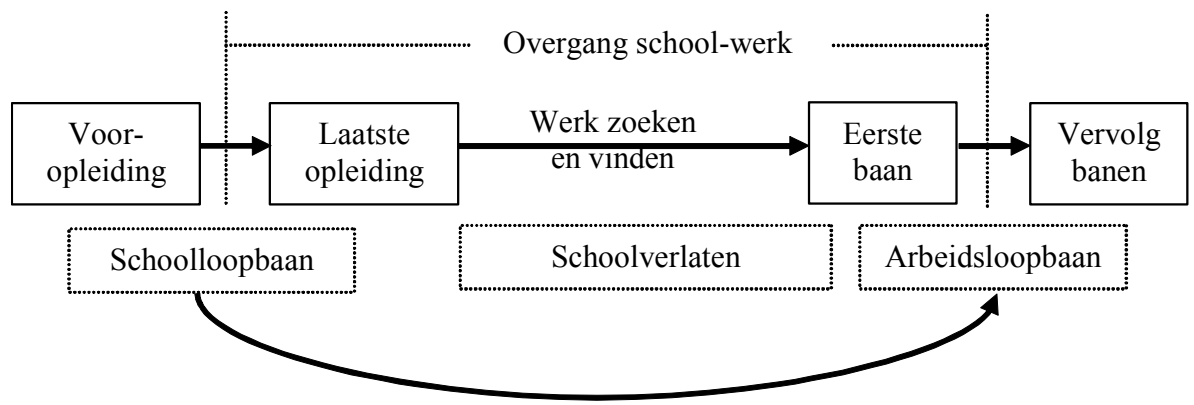

In Nederland zijn er twee belangrijke databronnen die gebruikt worden om de ontwikkelingen in de opbrengsten van onderwijs op de arbeidsmarkt te monitoren: de Enquête Beroepsbevolking (EBB) van het CBS en het Schoolverlatersinformatiesysteem (SIS) van het ROA. Beide databronnen kunnen deels als complementair worden beschouwd. Ze bevatten beide metingen van dezelfde concepten. Niet alle concepten zijn daarbij op dezelfde wijze geoperationaliseerd. Het is wenselijk dat er inzicht en - waar mogelijk afstemming komt over dit soort cijfers.

Voor een ander deel echter, bevatten beide bronnen verschillende informatie. De gegevens over de opbrengsten zijn dus ook deels gefragmenteerd. Er is kennisuitwisseling nodig tussen beide instituten over welke informatie van belang is bij het monitoren van de overgang van het onderwijs naar de arbeidsmarkt.

Naast de twee beschreven databronnen beschikt het CBS over een andere belangrijke databron die informatie kan genereren over het transitieproces: de VOCLschoolloopbaanonderzoeken. Deze geven een gedetailleerde beschrijving van de schoolloopbanen van grote groepen leerlingen gedurende de periode dat de leerling in de brugklas is gestart, tot aan het einde van de onderwijsloopbaan. In het kader 
van deze VOCL-schoolloopbaanonderzoeken heeft het CBS aanvullende metingen verricht onder degenen die het volledig dagonderwijs verlaten hebben: het zogeheten SVD. Deze gegevens zijn in het kader van dit project ontsloten voor analyse.

Een laatste bron van informatie zijn de registers waarover het CBS beschikt. Hierbij moet gedacht worden aan belastingregistraties zoals de aangifte voor de Inkomstenbelasting en de Enquête Werkgelegenheid en Lonen. Deze bronnen zijn beschikbaar in het Sociaal Statistisch Bestand (SSB). Een gedeeltelijke integratie van de verschillende databronnen stelt ons in staat het beste uit alle bronnen te gebruiken om tot zo optimaal mogelijke inzichten te komen over de transitie van school naar werk.

\subsection{Doelstelling}

Het thema Sociale Dynamiek en Arbeidsmarkt heeft als doel het ontwikkelen van nieuwe, geïntegreerde, samenhangende statistische persoonsinformatie over de arbeidsmarkt-, huishouden-, inkomen- en vermogensdynamiek. Met geïntegreerde persoonsinformatie wordt bedoeld dat statistieken tot stand komen door het samenvoegen van informatie uit díe bronnen die de informatie het beste bevatten. Integratie houdt echter ook in dat, bij discrepanties tussen definities in bronnen de beste wordt bepaald, zodat er overeenstemming wordt bereikt over de te gebruiken definitie. Op deze wijze wordt beoogd de transities die individuen gedurende hun verblijf op de arbeidsmarkt maken inzichtelijk te krijgen. Eén van de transities die in dit proces van cruciaal belang zijn, is de transitie van het onderwijs naar de arbeidsmarkt. Bovendien beoogt het CBS het verwerven van de benodigde kennis om zo efficiënt mogelijk gebruik te maken van verschillende bronnen en het integreren van deze bronnen in het loopbaanonderzoek.

Het samenwerkingsproject richt zich op de transitie van het onderwijs naar de arbeidsmarkt (zie figuur 1.1). Een gezamenlijke doelstelling van het CBS en het ROA is in de eerste plaats het verkrijgen van inzicht in de effecten van onderwijs, competenties en sociale en culturele hulpbronnen op de arbeidsmarktloopbaan. In de tweede plaats beogen beide instituten de statistische informatie van de transitie van onderwijs naar arbeidsmarkt te verbeteren. Het derde doel is het verwerven van kennis over relevante indicatoren dat zal bijdragen aan het zo efficiënt mogelijk uitvoeren van schoolloopbaan- en schoolverlatersonderzoek.

\subsection{Probleemstelling}

Bij het toewijzen van een arbeidsmarktpositie aan schoolverlaters speelt opleiding een belangrijke rol. Over het hoe en waarom bestaat echter nog aanzienlijke onzekerheid. In arbeidsmarkttheorieën wordt verschillend gedacht over de rol die opleiding speelt bij het toewijzen van posities op de arbeidsmarkt (zie voor een recent overzicht Bills (2003). Zo wijst Becker (1964) op het belang van menselijk kapitaal. Volgens deze theorie vertegenwoordigen de vaardigheden die in het onderwijs worden verkregen menselijk kapitaal. Investeringen hierin zijn zinvol zo lang als deze leiden tot een hogere productiviteit op de arbeidsmarkt. Werkgevers 
belonen arbeidsproductiviteit door de beste posities toe te kennen aan individuen met het meeste menselijk kapitaal. Thurow (1975) legt daarentegen liever de nadruk op trainbaarheid. Bij het selecteren van arbeidskrachten maken werkgevers een inschatting van de te maken trainingskosten. Hiertoe rangschikken zij potentiële arbeidskrachten in een denkbeeldige wachtrij. In deze rij staan vooraan degenen voor wie de trainingskosten het laagst zijn. Opleiding wordt daarbij gehanteerd als een aanwijzing voor trainbaarheid (Spence, 1973), een algemene vaardigheid die weer staat voor leervermogen en motivatie. Vanwege de geringere trainbaarheid van laagopgeleiden zijn de trainingskosten voor hen hoger dan voor hoogopgeleiden en staan zij daarom achteraan in de wachtrij van potentiële arbeidskrachten. Weer anderen stellen dat opleiding als een statusgoed moet worden opgevat (Bourdieu 1973; Collins 1979). Uitgangspunt hierbij is dat het onderwijs kinderen uit de hogere statusgroepen van de samenleving voorziet van kwalificaties. De statusaspecten van het onderwijs vormen een belangrijk selectiecriterium van werkgevers en degenen die over de meeste kwalificaties beschikken, hebben uitzicht op de beste posities op de arbeidsmarkt.

In dit rapport wordt onderzocht met welke mechanismen schoolverlaters worden toegewezen aan een positie op de arbeidsmarkt. Er wordt echter geen strikte toets geboden op de houdbaarheid van bovengenoemde theoretische benaderingen. In plaats daarvan wordt slechts verondersteld dat verschillende theorieën cognitieve vaardigheden, motivatie en ouderlijke hulpbronnen - naast natuurlijk het behaalde opleidingsniveau - als kenmerken beschouwen die allen afzonderlijk bijdragen aan het verklaren van de arbeidsmarktpositie van schoolverlaters (zie ook Kerckhoff et al., 2001). De centrale vraagstelling van dit rapport luidt dan ook als volgt:

In hoeverre kan het effect van opleiding op de arbeidsmarktpositie van schoolverlaters worden toegeschreven aan kenmerken van leerlingen die al aanwezig waren voor de start van de onderwijsloopbaan dan wel aan kenmerken die zijn opgedaan tijdens de onderwijsloopbaan?

Om deze onderzoeksvraag te beantwoorden en daarmee de 'black box' van het onderwijs te openen, wordt onderzocht in hoeverre deze kenmerken (dat wil zeggen cognitieve vaardigheden, soft skills en ouderlijke hulpbronnen) direct dan wel indirect (via het behaalde opleidingsniveau) de arbeidsmarktpositie van schoolverlaters bepalen. Eerst wordt bestudeerd in welke mate deze kenmerken van invloed zijn op het hoogst behaalde opleidingsniveau van schoolverlaters. Vervolgens wordt het effect van deze kenmerken op de arbeidsmarktpositie van schoolverlaters vastgesteld.

\subsection{Opzet van dit rapport}

Dit rapport is als volgt opgebouwd. In hoofdstuk 2 worden de data die voor de analyses gebruikt worden beschreven. Bovendien zal worden ingegaan op de vooren nadelen van de gebruikte data. In hoofdstuk 3 laten we zien wat de directe relatie is tussen het opleidingsniveau en de opleidingsrichting van schoolverlaters enerzijds en hun arbeidsmarktkansen anderzijds. Een aantal kenmerken van de arbeids- 
marktpositie van schoolverlaters komen aan bod, zoals de kans op werk en het loon. In hoofdstuk 4 worden de verklarende analyses uitgevoerd waarbij onder andere wordt nagegaan welke kenmerken naast opleidingsniveau en opleidingsrichting bepalend zijn voor arbeidsmarktsucces. Daarbij gaat het onder meer om cognitieve kenmerken, 'soft skills' en sociale en culturele hulpbronnen. Hierbij wordt ook ingegaan op de indirecte relatie tussen onderwijs- en arbeidsmarktsucces. In het laatste hoofdstuk volgen dan de conclusies en aanbevelingen voor vervolgonderzoek. 


\section{Datamateriaal}

De gegevens die in dit onderzoek worden geanalyseerd, zijn afkomstig van het Voortgezet Onderwijs Cohort Leerlingen 1989 (VOCL'89). Het betreft 19.254 leerlingen afkomstig van een aselecte steekproef van 381 scholen die in het schooljaar 1989/1990 in het eerste leerjaar van het voortgezet onderwijs zaten en van wie sindsdien de onderwijsloopbaan wordt gevolgd. Dit houdt onder meer in dat jaarlijks wordt vastgesteld in welk leerjaar van welk schooltype de leerlingen zitten. Hierdoor is het niet alleen mogelijk steeds het onderwijsniveau te bepalen, maar ook of er sprake is van doubleren en drop-out, en van op- dan wel afstroom naar een hoger respectievelijk lager schooltype. Bovendien zijn in het eerste en derde leerjaar toetsen met betrekking tot schoolprestaties en non-verbale intelligentie afgenomen. Het betreft hier dus metingen van kenmerken van leerlingen die aanwezig waren voorafgaand aan de start van de opleiding. Daarnaast is bij de start van het onderzoek een schriftelijke vragenlijst afgenomen bij de ouders van de leerlingen met als doel om informatie over gezins- en leerlingkenmerken te verzamelen. In grote lijnen kan de steekproef als representatief worden beschouwd voor alle leerlingen die in het schooljaar 1989/1990 in het eerste leerjaar van het voortgezet onderwijs zaten (CBS, 1991; Driessen \& Van der Werf, 1992).

De meeste leerlingen van het VOCL'89 hebben inmiddels het reguliere, voltijd dagonderwijs verlaten. Om te achterhalen wat deze leerlingen zijn gaan doen na het verlaten van het onderwijs, is sinds 1994 een schoolverlatersonderzoek gekoppeld aan het VOCL'89. Op deze manier kan worden waargenomen hoe voor schoolverlaters de transitie van school naar werk is verlopen. De telefonische vragenlijst bestaat uit een selectie van de vragen die worden gesteld in de Enquête Beroepsbevolking (EBB). Het betreft vragen over onder andere de werkkring, het soort dienstverband en het aantal arbeidsuren (zie voor een uitgebreide beschrijving CBS, 2004). Uit de totale steekproefpopulatie van het VOCL'89 zijn inmiddels 17.047 leerlingen benaderd voor dit schoolverlatersonderzoek. ledere schoolverlater heeft ongeveer anderhalf jaar na het schoolverlaten eenmalig de telefonische vragenlijst voorgelegd gekregen. $\mathrm{Na}$ selectie van degenen die daadwerkelijk hebben deelgenomen aan het schoolverlatersonderzoek, en die geen voltijd onderwijs meer zijn gaan volgen na het schoolverlaten, blijft een analytische steekproef over van maximaal 12.939 schoolverlaters (zie bijlage 1).

De informatie over het loon is afkomstig uit het Regionaal Inkomensonderzoek (RIO) en gekoppeld aan het VOCL'89. Het RIO is een steekproefonderzoek met een dekking van ongeveer $30 \%$. Daardoor kon niet voor alle respondenten van het VOCL'89 het jaarloon achterhaald worden. Bovendien zijn alleen de loongegevens voor de jaren 1995 tot en met 2000 koppelbaar via Sociaal Statistisch Bestand. Dit betekent dat voor slechts 3.740 schoolverlaters het loon bekend is. 


\subsection{Consequenties van paneldesigns}

Het VOCL cohort is een panelonderzoek. Dit betekent dat alle schoolverlaters op het zelfde moment zijn gestart in het onderwijs, en dat vervolgens ieder jaar een deel van die leerlingen uit het onderwijs stroomt en de arbeidsmarkt betreedt. De laagst opgeleiden zijn in het midden van de jaren ' 90 op de arbeidsmarkt gekomen, toen de werkloosheid hoog was, en het moeilijk was een baan te vinden. De hoog opgeleiden betraden de arbeidsmarkt pas later, toen de arbeidsmarkt gunstiger was en het makkelijker was een baan te vinden. De jaarlijkse uitstroom van leerlingen naar onderwijsniveau is weergegeven in tabel 2.1. Zoals blijkt uit de tabel ligt per jaar duidelijk het zwaartepunt van de uitstroom bij één opleiding. Zo is bijvoorbeeld in 1994 en 1995 ongeveer de helft van de schoolverlaters afkomstig uit het VBO, terwijl in 2002 ruim 60 procent van de uitstroom een HBO diploma heeft behaald.

Tabel 2.1

Verdeling uitstroom naar jaar van waarneming en onderwijsniveau

\begin{tabular}{lrrrrrrrrrrr}
\hline & 1994 & 1995 & 1996 & 1997 & 1998 & 1999 & 2000 & $2001^{2}$ & 2002 & 2003 & Totaal \\
\hline BO & 29,9 & 23,2 & 11,5 & 4,6 & 1,6 & 0,6 & 0,4 & - & - & - & 1399 \\
MAVO & 10,3 & 20,7 & 21,7 & 13,8 & 12,1 & 6,9 & 4,4 & 2,4 & 2,3 & 2,0 & 1592 \\
VBO & $\mathbf{5 8 , 6}$ & $\mathbf{5 0 , 3}$ & $\mathbf{2 8 , 6}$ & 10,5 & 6,7 & 3,8 & 1,2 & - & 0,7 & 0,4 & 3062 \\
HAVO & - & 3,3 & 9,1 & 5,5 & 4,5 & 4,0 & 3,2 & 14,3 & 1,3 & 2,7 & 504 \\
VWO & - & - & 7,0 & 5,0 & 3,2 & 3,3 & 3,4 & 2,4 & 1,5 & 3,2 & 369 \\
MBO & 0,1 & 0,7 & 21,0 & $\mathbf{6 0 , 1}$ & $\mathbf{7 0 , 7}$ & $\mathbf{6 1 , 2}$ & 35,5 & 28,6 & 15,1 & 10,8 & 3954 \\
HBO & - & - & - & - & 0,1 & 15,2 & $\mathbf{4 9 , 9}$ & $\mathbf{4 7 , 6}$ & $\mathbf{6 5 , 8}$ & 40,2 & 1475 \\
WO $^{3}$ & - & - & - & 0,2 & 1,0 & 2,2 & 1,9 & 4,8 & 13,2 & $\mathbf{4 0 , 5}$ & 499 \\
Totaal & & & & & & & & & & & \\
(N=100\%) & 2.097 & 2.004 & 1.544 & 2.029 & 1.632 & 1.062 & 978 & 42 & 710 & 841 & 12.939 \\
\hline
\end{tabular}

Bron: Schoolverlatersdata VOCL'89, 1994-2003, Centraal Bureau voor de Statistiek

Om het arbeidsmarktsucces van schoolverlaters met verschillende opleidingen goed te kunnen vergelijken zou men moeten corrigeren voor verschillen in uitstroommomenten. Hierdoor kunnen verschillen in arbeidsmarktsucces die te wijten zijn aan het conjuncturele klimaat onderscheiden worden van arbeidsmarktsucces door het opleidingsniveau dat men heeft behaald. Doordat alle leerlingen in het VOCL op het zelfde moment hun onderwijsloopbaan zijn gestart, maar de duur van de loopbaan wordt bepaald door het onderwijsniveau, hangt het moment van instroom op de arbeidsmarkt sterk samen met het hoogst behaalde onderwijsniveau. Het is hierdoor onmogelijk om cohort, leeftijd, en periode-effecten te onderscheiden. Een belangrijk periode-effect in dit onderzoek is het conjuncturele klimaat. Onder slechte conjuncturele omstandigheden is het immers moeilijker om een baan te vinden. Met deze dataset is het echter niet mogelijk hiervoor te controleren. Zoals gezegd hangt het

2. In 2001 is geen vragenlijst uitgegaan. Wel is een klein deel van de populatie die in het kalenderjaar 2000 ondervraagd had moeten worden verschoven naar 2001, het betreft hier 42 personen.

3. De uitstroom van het WO is lager dan verwacht, omdat een deel van de VOCL leerlingen nog in het onderwijs zit. Hierdoor zijn de resultaten voor de WO leerlingen niet helemaal representatief. 
uitstroommoment sterk samen met het opleidingsniveau (ter illustratie: bijna driekwart van de uitstroom in 1998 waren MBO-ers). Wanneer men in een multivariaat model achtereenvolgens zou controleren voor zowel onderwijsniveau als voor uitstroomjaar, dan wordt in feite twee keer voor het zelfde gecontroleerd. Het gevolg hiervan is dat het effect van het uitstroommoment het effect van het opleidingsniveau 'opblaast'. Het opleidingseffect wordt dan overschat. Een uitgebreide beschrijving van de problematiek en de overwegingen ten aanzien van dit project staan beschreven in bijlage 2 .

\subsection{Variabelen en operationalisaties}

Om de onderzoeksvraag te beantwoorden en daarmee de 'black box' van het onderwijs te openen, wordt onderzocht in hoeverre cognitieve vaardigheden, soft skills en ouderlijke hulpbronnen direct dan wel indirect (via het behaalde opleidingsniveau) de arbeidsmarktpositie van schoolverlaters bepalen. In deze paragraaf wordt beschreven welke operationalisaties zijn gebruikt en hoe de univariate verdelingen van de gebruikte variabelen eruit zien. Een uitgebreide beschrijving van de variabelen is bijgevoegd in bijlage 3 . In tabel 2.2 is een statistisch overzicht weergegeven van de variabelen die zijn gebruikt in de betreffende analyses.

De cognitieve vaardigheden van de schoolverlater zijn gemeten in twee variabelen; de schoolprestaties en de non-verbale intelligentie. Beiden zijn gemeten in het eerste leerjaar van het voorgezet onderwijs. De schoolprestaties zijn gemeten aan de hand van drie afzonderlijke deeltoetsen: Nederlands, rekenen en informatieverwerking. De scores van de afzonderlijke toetsen zijn samengevoegd tot een totaalscore. De intelligentietoets bestond uit twee onderdelen: een subtest voor het redeneervermogen en een subtest voor het abstractievermogen. Ook deze twee subtesten zijn samengevoegd tot één meting van de non-verbale intelligentie.

De prestatiemotivatie en de schoolbeleving worden gerekend tot de soft skills. Beide kenmerken zijn gemeten in het eerste jaar van het voortgezet onderwijs. De prestatiemotivatie zegt iets over de drijfveer om succesvol te zijn op school. Schoolbeleving beoogt een indicatie te geven van de mate waarin men het naar zijn zin heeft op school. Beide kenmerken zijn gemeten aan de hand van uitspraken die aan de leerling zijn voorgelegd.

De ouderlijke hulpbronnen zijn gemeten in een aantal kenmerken: het opleidingsniveau van de ouders, de maatschappelijke positie van de ouders, de culturele participatie van de ouders, het leesgedrag en het onderwijsondersteunende thuisklimaat. De ouderkenmerken zijn gemeten via een vragenlijst aan de ouders die in het eerste leerjaar van het voortgezet onderwijs aan de leerlingen mee naar huis is gegeven. Het opleidingsniveau van de ouders is bepaald aan de hand van het gemiddelde opleidingsniveau van de ouders. De maatschappelijke positie van de ouders is gemeten aan de hand van informatie over de werkzaamheid en het beroep van de hoofdkostwinner van het gezin. De culturele participatie en het leesgedrag zijn gemeten aan de hand van vragen over onder andere museumbezoek, het bezoeken van balletvoorstellingen en het leesgedrag van de ouders. Het onderwijs- 
ondersteunende thuisklimaat zegt iets over de interesse die de ouders uiten voor de schoolprestaties van hun kind en het welbevinden op school.

Tabel 2.2

Statistische beschrijving van de gebruikte variabelen

\begin{tabular}{|c|c|c|c|c|c|c|}
\hline & $\begin{array}{l}\text { Gemid- } \\
\text { delde }\end{array}$ & $\begin{array}{l}\text { Standaard- } \\
\text { afwijking }\end{array}$ & $\begin{array}{l}\text { Percen- } \\
\text { tage }\end{array}$ & Minimum & Maximum & $\mathrm{N}$ \\
\hline Opleidingsniveau & 12,19 & 3,30 & & 6 & 19 & 12.939 \\
\hline $\begin{array}{l}\text { Aanvullende scholing } \\
\text { zonder diploma }\end{array}$ & & & & & & \\
\hline $\begin{array}{l}\text { zonder diploma } \\
\text { Studievertraging }\end{array}$ & & & $\begin{array}{l}13 \\
26\end{array}$ & & & $\begin{array}{l}12.939 \\
12.939\end{array}$ \\
\hline \multicolumn{7}{|l|}{ Sekse } \\
\hline Man & & & 48 & & & 12.939 \\
\hline Vrouw & & & 52 & & & 12.939 \\
\hline \multicolumn{7}{|l|}{ Etniciteit } \\
\hline Autochtoon & & & 89 & & & 12.939 \\
\hline Allochtoon & & & 11 & & & 12.939 \\
\hline \multicolumn{7}{|l|}{ Opleidingsrichting } \\
\hline Algemeen & & & 29 & & & 12.939 \\
\hline Landbouw & & & 3 & & & 12.939 \\
\hline Techniek & & & 25 & & & 12.939 \\
\hline Economie & & & 16 & & & 12.939 \\
\hline Gezondheidszorg & & & 18 & & & 12.939 \\
\hline Overig & & & 9 & & & 12.939 \\
\hline \multicolumn{7}{|l|}{ Regio } \\
\hline Randstad & & & 33 & & & 12.937 \\
\hline Overig & & & 67 & & & 12.937 \\
\hline Schoolprestaties & 0,50 & 0,29 & & 0,00 & 0,97 & 12.939 \\
\hline Non-verbale intelligentie & 0,50 & 0,24 & & 0,00 & 1,00 & 12.701 \\
\hline Prestatiemotivatie & 0,50 & 0,27 & & 0,00 & 0,79 & 12.294 \\
\hline Schoolbeleving & 0,50 & 0,29 & & 0,00 & 0,99 & 12.322 \\
\hline Opleidingsniveau ouders & 10,66 & 3,24 & & 6 & 19 & 12.519 \\
\hline \multicolumn{7}{|l|}{$\begin{array}{l}\text { Maatschappelijke positie } \\
\text { ouders }\end{array}$} \\
\hline Niet werkzaam & & & 18 & & & 12.528 \\
\hline Arbeider & & & 32 & & & 12.528 \\
\hline \multicolumn{7}{|l|}{ Zelfstandige zonder } \\
\hline personeel & & & 5 & & & 12.528 \\
\hline \multicolumn{7}{|l|}{ Zelfstandige met } \\
\hline personeel & & & 4 & & & 12.528 \\
\hline Lagere employee & & & 9 & & & 12.528 \\
\hline Middelbare employee & & & 19 & & & 12.528 \\
\hline Hogere employee & & & 13 & & & 12.528 \\
\hline \multicolumn{7}{|l|}{ Culturele participatie } \\
\hline ouders & 0,48 & 0,28 & & 0,18 & 1,00 & 11.186 \\
\hline Leesgedrag ouders & 0,49 & 0,28 & & 0,10 & 1,00 & 11.234 \\
\hline \multicolumn{7}{|l|}{ Onderwijsondersteunend } \\
\hline thuisklimaat & 0,50 & 0,26 & & 0,00 & 0,72 & 11.267 \\
\hline Schooladvies & 6,91 & 1,00 & & 5 & 9 & 12.510 \\
\hline \multicolumn{7}{|l|}{ Werkzame } \\
\hline beroepsbevolking & & & 95 & & & 11.025 \\
\hline Vast werk & & & 86 & & & 11.129 \\
\hline Baan op niveau & & & 62 & & & 10.040 \\
\hline \multirow{3}{*}{$\begin{array}{l}\text { Baan in richting } \\
\text { Beroepsprestige } \\
\text { Persoonlijk bruto } \\
\text { jaarloon }\end{array}$} & & & 59 & & & 7.511 \\
\hline & 37,70 & 16,48 & & 15 & 86 & 9.640 \\
\hline & 11.103 & 6.795 & & 13 & 63.549 & 3.740 \\
\hline
\end{tabular}

Bron: Schoolverlatersdata VOCL'89, 1994-2003, Regionaal Inkomens Onderzoek 1995-2000, Centraal Bureau voor de Statistiek 
Naast deze drie groepen van onafhankelijke variabelen zijn ook een aantal achtergrondkenmerken gebruikt. Het gaat hier om sekse, etniciteit en de regio waar de schoolverlater woonde op het meetmoment (anderhalf jaar na het verlaten van de opleiding). Bovendien is een aantal onderwijskenmerken opgenomen: het hebben van aanvullende scholing na het hoogst behaalde onderwijs zonder daarvan een diploma te hebben behaald, het al dan niet hebben opgelopen van studievertraging in de laatste opleiding en het schooladvies dat de leerling kreeg in groep acht van de basisschool.

In dit rapport worden zeven verschillende afhankelijke variabelen gebruikt:

- Het hoogst behaalde opleidingsniveau. Deze is geoperationaliseerd volgens de leerjarenladder (zie bijlage 3)

- De werkzame beroepsbevolking. Deze wordt gebruikt om de kans op werk te bepalen. De werkzame beroepsbevolking is gemeten als $100 \%$ - het \% werklozen in de totale populatie. De werkzaamheid van de schoolverlater is, evenals de overige arbeidsmarktkenmerken, gemeten toen de schoolverlater gemiddeld anderhalf jaar uit het onderwijs was vertrokken

- Vast werk. Tot de schoolverlaters met vast werk worden degenen gerekend die óf (deels) in vaste dienst zijn óf die bij goed functioneren in vaste dienst komen óf die een contract hebben van een jaar of langer

- Baan op niveau. Schoolverlaters hebben een baan op niveau als het niveau van de baan overeen komt of hoger is dan het niveau van de hoogst behaalde opleiding.

- Baan in de richting. Schoolverlaters hebben een baan in de richting als de richting van de hoogst behaalde opleiding overeen komt met de richting van de baan

- Beroepsprestige. Het beroepsprestige is een meting van het aanzien dat een beroep geniet in de maatschappij (Sixma en Ultee, 1984). Het wordt bepaald aan de hand van het beroep dat de schoolverlater uitoefende op het meetmoment.

- Persoonlijk bruto jaarinkomen. Het persoonlijk bruto jaarinkomen is een optelsom van het genoten inkomen in het jaar van meten. In tegenstelling tot de andere arbeidsmarktkenmerken is het inkomen niet via een vragenlijst gemeten maar gekoppeld uit een externe bron, het Regionaal Inkomens Onderzoek. 



\section{Beschrijvende analyses}

In dit hoofdstuk wordt een beschrijving gegeven van de arbeidsmarktpositie van schoolverlaters, anderhalf jaar na het verlaten van de opleiding. Dit wordt uitgesplitst naar opleidingsniveau en opleidingssector. Hierbij komen de volgende kenmerken aan bod: werkloosheid, de kans op vast werk, het hebben van een baan die qua niveau of richting aansluit bij de gevolgde opleiding, het persoonlijk bruto jaarloon en het beroepsprestige. Het gaat hier om kruistabellen, dat wil zeggen om bivariate effecten zonder dat er gecontroleerd wordt voor andere kenmerken van schoolverlaters. Alvorens over te gaan op de bivariate effecten van het opleidingsniveau op de arbeidsmarktpositie wordt eerst een beschrijving gegeven van de conjunctuurgevoeligheid van de gebruikte arbeidsmarktkenmerken.

\subsection{De conjunctuurgevoeligheid van arbeidsmarktkenmerken}

Jaarlijks voert het ROA uitgebreid onderzoek uit naar de arbeidsmarktpositie van schoolverlaters. Op basis van die gegevens is een onderzoek gedaan naar de ontwikkelingen in de overgang van school naar werk in de periode 1992-2001 (ROA, 2002). Hierbij ging het vooral om het in kaart brengen van conjuncturele en meer structurele ontwikkelingen. Hieronder staan de bevindingen van het ROA beschreven ten aanzien van de arbeidsmarktkenmerken die in dit rapport worden onderscheiden:

Wat betreft de werkloosheid bleek dat deze veel dynamiek vertoonde. De werkloosheid nam in de eerste helft van de jaren negentig nog toe om vervolgens in 1997 scherp te dalen. Bij het HBO heeft deze daling eerder ingezet (namelijk al in 1995) dan bij het VBO en het MBO. Opvallend is dat voor het VBO en het KMBO de werkloosheid recent weer lijkt toe te nemen als gevolg van de teruggang in de conjunctuur, terwijl de werkloosheid voor de hogere opleidingen op een zeer laag niveau blijft. Dit duidt erop dat de lagere opleidingsniveaus eerder én langer geconfronteerd worden met ongunstige arbeidsmarktomstandigheden.

Ook het hebben van vast werk is gedeeltelijk conjunctuurgevoelig gebleken. In het algemeen is het aantal schoolverlaters dat in tijdelijke banen werkzaam is kleiner dan het aantal dat in vaste banen werkt. Het percentage vaste aanstellingen daalde voor de meeste opleidingsniveaus tot 1996 om vervolgens weer te stijgen. Daarmee lijkt deze indicator eerder de conjuncturele ontwikkeling te volgen en dus samen te hangen met de ontwikkelingen in de werkgelegenheid. Sterker nog, voor elk van de onderscheiden opleidingsniveaus blijkt het percentage vaste aanstellingen voor schoolverlaters in 2001 boven het niveau van 1992 te liggen. Er is dus zeker geen sprake van een structurele trend naar meer tijdelijke aanstellingen. De verschillen tussen de opleidingsniveaus zijn niet erg systematisch. Het percentage vaste aanstellingen ligt over de gehele periode het hoogst bij KMBO gevolgd door het $\mathrm{HBO}$. Het percentage vaste aanstellingen ligt relatief laag bij het VBO en het WO. Voor beide opleidingsniveaus geldt dat een relatief grote groep werk combineert met een opleiding, waarbij doorgaans een tijdelijk contract voor de opleidingsperiode 
wordt geboden. Voor het VBO is dat de groep die naar de BBL (het vroegere leerlingwezen) gaat en voor het WO zijn dit de AiO's, OiO's en AGiO's.

Ook de ontwikkelingen in de reële lonen sporen bij het $\mathrm{HBO}$, en tevens bij het WO, nauw met de ontwikkelingen in de vraag-aanbod verhoudingen, met relatief lage lonen in de eerste helft van de jaren negentig en relatief hoge lonen in de tweede helft. Bij de lagere opleidingsniveaus blijkt de ontwikkeling in de reële lonen veel minder dynamiek te vertonen en meer door institutionele factoren dan door arbeidsmarktomstandigheden verklaard te worden.

De ontwikkelingen in de kwalitatieve aansluiting tussen opleiding en beroep laten een gemengd beeld zien. Bij het $\mathrm{HBO}$ is de kans om een baan te verwerven op HBOniveau stabiel hoog en hangt niet samen met veranderingen in vraag-aanbod verhoudingen. Ook de aansluiting naar opleidingsrichting hangt niet samen met de arbeidsmarktomstandigheden, en vertoont zelfs een structurele trend waarbij steeds meer afgestudeerden werkzaam zijn in beroepen buiten de eigen richting, ondanks de gespannen arbeidsmarkt. Dit duidt eerder op verbreding van de betreffende opleidingen of een zuigkracht vanuit andere segmenten dan op een verslechtering van de arbeidsmarktpositie. Bij het WO daarentegen hangt de kans om in een baan werkzaam te zijn die aansluit bij het behaalde opleidingsniveau en de gevolgde opleidingsrichting wel degelijk nauw samen met de arbeidsmarktomstandigheden. In het geval van ongunstige vraag-aanbod verhoudingen wijken de afgestudeerden van het WO uit naar banen op lager niveau of banen buiten het eigen beroependomein. Dit verschil in aanpassingsmechanismen tussen WO en HBO hangt nauw samen met het sterker beroepsgerichte karakter van het $\mathrm{HBO}$ alsmede met het feit dat de grens tussen WO- en HBO-beroepen vager is dan de grens tussen HBO- en MBOberoepen. WO-afgestudeerden kunnen daarom ook makkelijker uitwijken naar andere banen. Bij het MBO en het VBO vertoont de ontwikkeling in de kwalitatieve aansluiting een grilliger patroon en blijken ook de vraag-aanbod verhoudingen aan meer schommelingen onderhevig.

\subsection{Werkloosheid en vast werk}

In deze paragraaf wordt ingegaan op de kans op werkloosheid en vast werk. Figuur 3.1 laat de kans op werkloosheid zien voor de schoolverlaters uit het VOCL'89. Het gaat hierbij om de situatie anderhalf jaar na schoolverlaten. De kans op het vinden van werk wordt voor schoolverlaters relatief sterk beïnvloed door de conjuncturele omstandigheden op het moment dat men werk zoekt (ROA, 2002). Omdat in deze analyses geen correctie is uitgevoerd voor verschillen in conjunctureel klimaat moet men vooral bij de kans op werk oppassen met vergelijkingen tússen de verschillende opleidingsniveaus. Deze schoolverlaters zijn immers niet in het zelfde jaar van school gekomen (zie tabel 2.1).

Het grote verschil in werkloosheid doet zich vooral voor tussen basisonderwijs, VBO en AVO enerzijds en MBO of hoger anderzijds. Dit valt min of meer samen met het onderscheid tussen het wel of niet hebben van een startkwalificatie. Daarnaast blijkt uit figuur 3.1 dat schoolverlaters met een technische opleiding relatief het minst vaak 
werkloos zijn in vergelijking met schoolverlaters uit andere onderwijssectoren. Binnen het $\mathrm{VBO}$ en het $\mathrm{MBO}$ is de werkloosheid het hoogst onder schoolverlaters met de richting economie en gezondheidszorg. Het beeld voor $\mathrm{HBO}$ en WO schoolverlaters wijkt hier iets van af. In het HBO zijn het alleen de schoolverlaters uit de sector economie die iets vaker werkloos zijn, terwijl binnen het WO juist alleen de schoolverlaters uit de sector techniek te lijden hebben onder een iets hogere werkloosheid. Voor het WO moet echter enige voorzichtigheid in acht worden genomen gezien het feit dat de onderzoeksgroep nog niet volledig is uitgestroomd.

Figuur 3.1

Percentage werkloze schoolverlaters per opleidingsniveau en opleidingssector

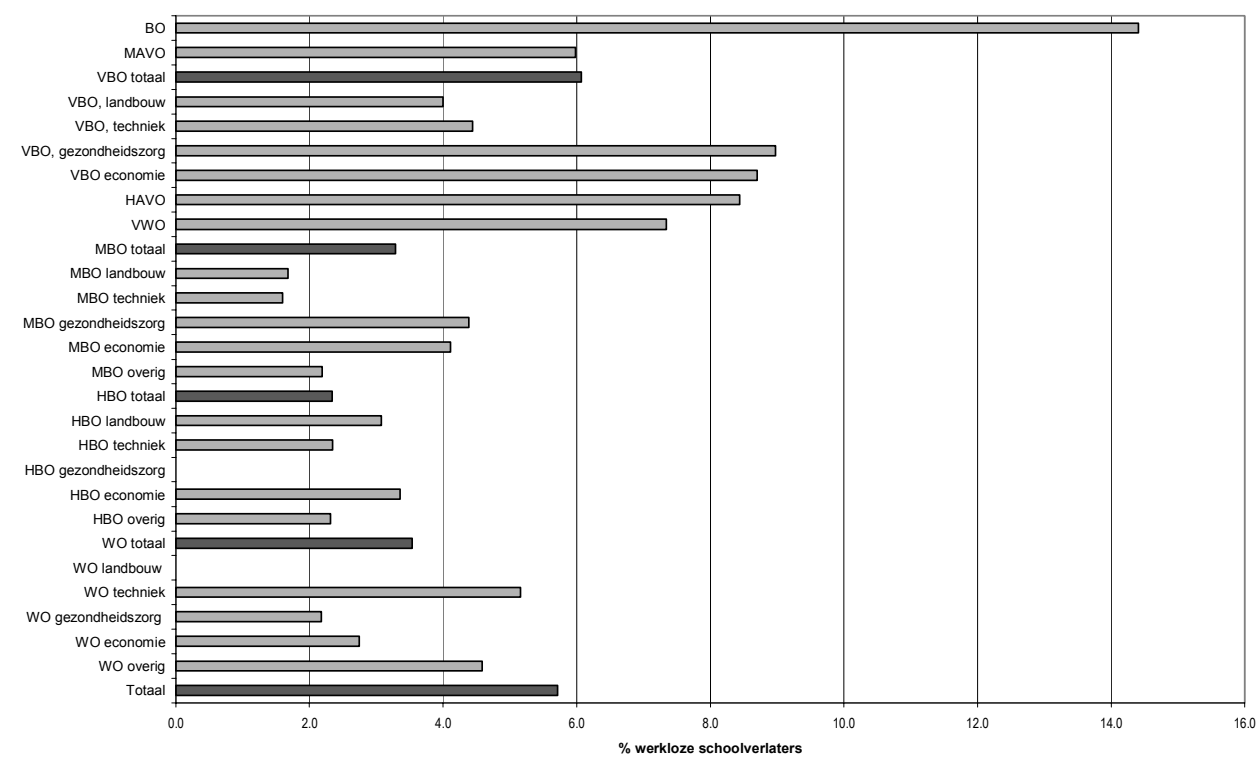

Bron: Schoolverlatersdata VOCL'89, 1994-2003, Centraal Bureau voor de Statistiek

Wat betreft de kans op vast werk zijn, met uitzondering van basisonderwijs, de verschillen naar niveau in het algemeen niet groot. Wel neemt kans op vast werk toe naarmate het opleidingsniveau hoger is. Laag opgeleiden werken vaker in tijdelijke dienstverbanden dan hoog opgeleiden. Binnen het VBO, het MBO en het $\mathrm{HBO}$ geldt dat schoolverlaters uit de sector economie het minst vaak een vaste aanstelling hebben in vergelijking tot de schoolverlaters uit de andere onderwijssectoren. Binnen het WO zijn het vooral degenen met een opleiding in de technische richting die relatief vaak een vaste aanstelling hebben. De werkzekerheid is relatief hoog in de sectoren landbouw en techniek. Dat geldt voor schoolverlaters uit zowel het VBO, het $\mathrm{MBO}$ als het WO. Alleen in het $\mathrm{HBO}$ is een iets afwijkend patroon te zien. Binnen het $\mathrm{HBO}$ zijn het met name de opleidingen in de technische en economische richtingen die tot een relatief hoge mate van werkzekerheid leiden. Dit beeld komt grotendeels overeen met de bevindingen van het ROA (ROA, 2003). 
Figuur 3.2

Percentage schoolverlaters met een vaste aanstelling per opleidingsniveau en opleidingssector

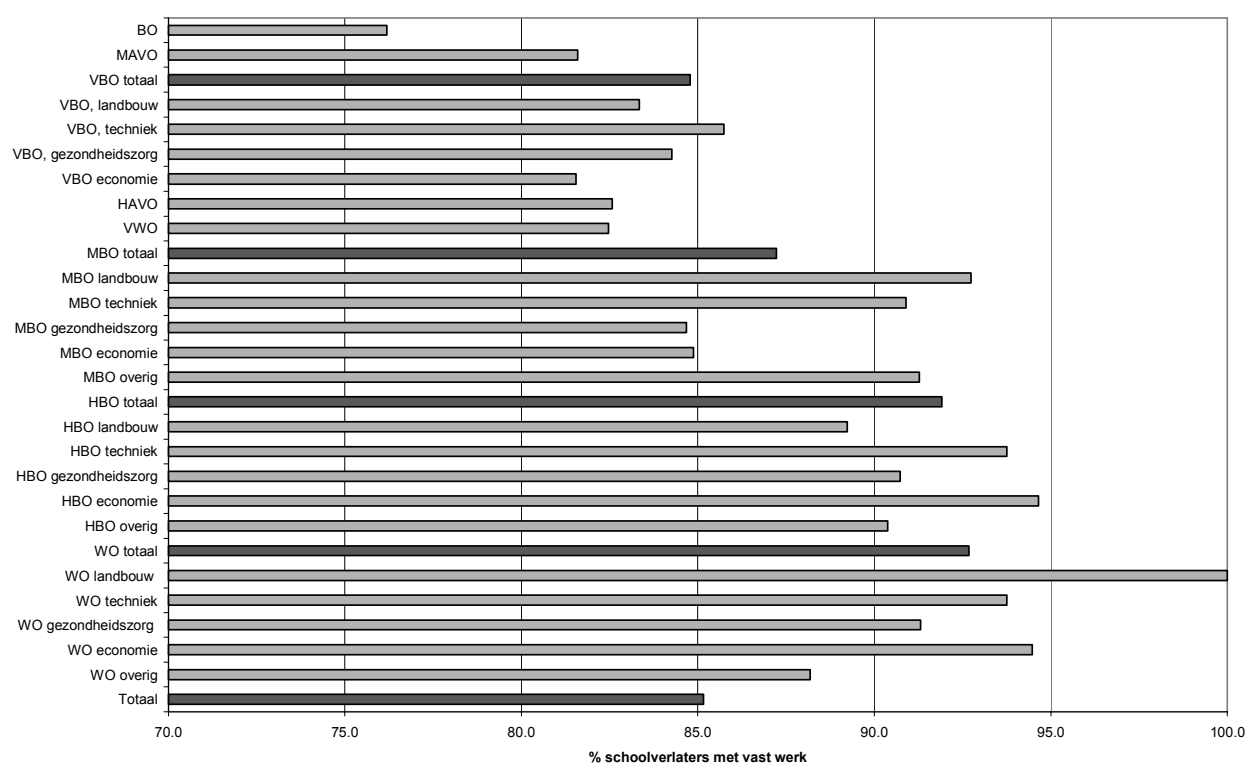

Bron: Schoolverlatersdata VOCL'89, 1994-2003, Centraal Bureau voor de Statistiek

\subsection{De aansluiting tussen de opleiding en de baan}

Bij het intreden tot de arbeidsmarkt vormt het behaalde onderwijsniveau een belangrijke basis voor de baan waarin de schoolverlater gaat werken. Hierbij is het van belang dat de genoten opleiding goed aansluit bij het beroep dat men gaat uitoefenen. In figuur 3.3 staat per opleidingsniveau en per opleidingssector aangegeven welk percentage schoolverlaters anderhalf jaar na het schoolverlaten een baan uitoefende op het zelfde niveau als de opleiding die ze hadden afgerond.

De laagst opgeleiden hebben vaker een baan op niveau dan hoger opgeleiden. Dit is echter niet vreemd aangezien er voor de laagst opgeleiden nauwelijks banen zijn van een lager niveau. Hoogopgeleiden hebben daarentegen meer mogelijkheden om uit te wijken naar een baan beneden hun behaalde opleidingsniveau.

Naast verschillen tussen opleidingsniveaus blijkt dat ook de opleidingsrichting van invloed is op de kans dat men werk op niveau vindt. Over het algemeen kan men stellen dat schoolverlaters met een technische opleiding binnen alle opleidingsniveaus relatief het vaakst een baan op niveau hebben. Alleen onder WO afgestudeerden hebben degenen met opleidingen in de sector gezondheidszorg vaker een baan op niveau dan degenen met een technische achtergrond. Dit beeld komt overeen met de resultaten van het ROA onderzoek.

Naast het hebben van een baan op het niveau van de genoten opleiding is ook het hebben van een baan in de richting van de genoten opleiding belangrijk. In figuur 3.4 
is daarom weergegeven hoeveel procent van de schoolverlaters anderhalf jaar na het verlaten van de opleiding een baan heeft die aansluit bij de richting van de gevolgde opleiding.

\section{Figuur 3.3}

Percentage schoolverlaters met een baan op het niveau van de hoogst behaalde opleiding per opleidingsniveau en opleidingssector

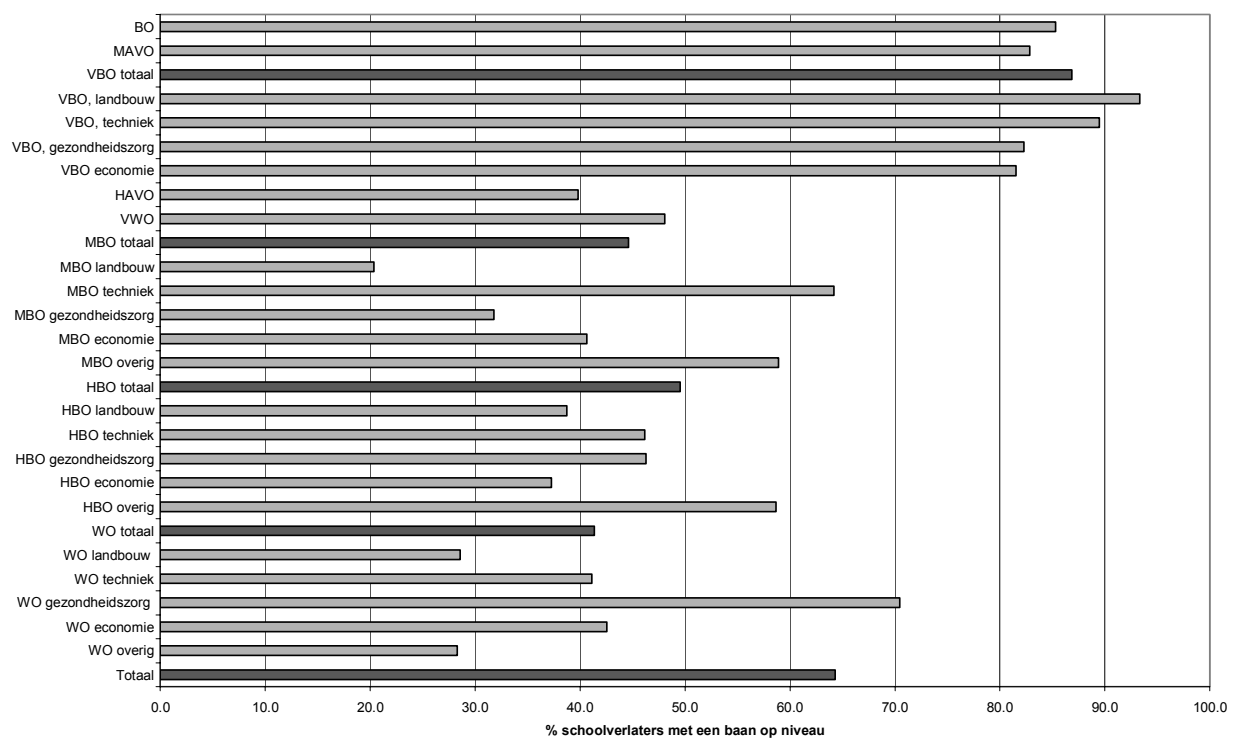

Bron: Schoolverlatersdata VOCL'89, 1994-2003, Centraal Bureau voor de Statistiek

\section{Figuur 3.4}

Percentage schoolverlaters met baan in de richting van de hoogst behaalde opleiding per opleidingsniveau en opleidingssector

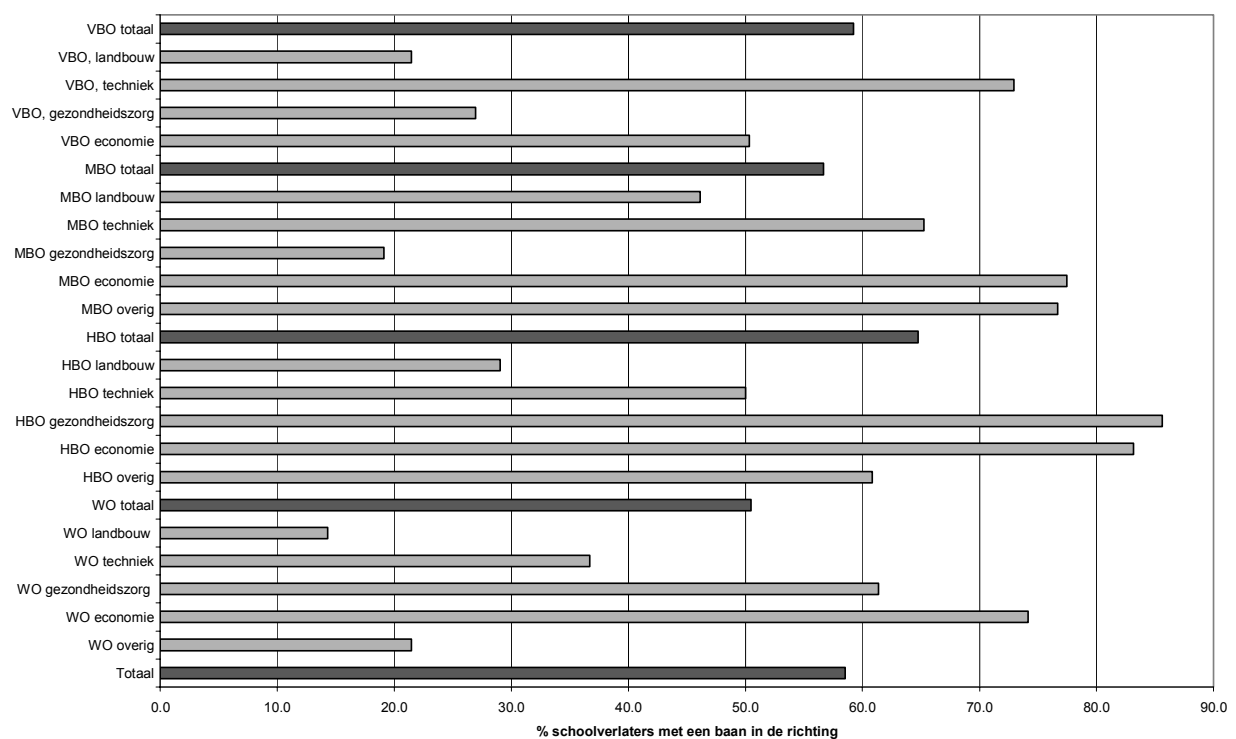

Bron: Schoolverlatersdata VOCL'89, 1994-2003, Centraal Bureau voor de Statistiek 
Schoolverlaters uit het lager en middelbare beroepsonderwijs met een technische achtergrond blijken niet alleen relatief vaak een baan te hebben die aansluit bij hun opleidingsniveau, ze blijken ook vaker dan schoolverlaters uit andere opleidingsrichtingen een baan te hebben die aansluit bij hun opleidingsrichting. Onder schoolverlaters met een HBO diploma blijkt dat degenen met een opleiding in de richting gezondheidszorg of economie vaak een baan hebben gevonden die aansluit bij hun opleidingsrichting. Bij het WO zijn het voornamelijk de economen die een baan hebben gevonden die aansluit bij de gevolgde opleidingsrichting.

Voor schoolverlaters van de sector landbouw geldt voor alle opleidingsniveaus dat ze minder vaak een baan hebben gevonden die qua richting aansluit bij de gevolgde opleiding. Alleen voor MBO-schoolverlaters binnen de sector gezondheidszorg geldt dat zij nog minder vaak een baan in de eigen richting hebben gevonden.

\subsection{Loon en beroepsprestige}

In figuur 3.5 staat het gemiddelde persoonlijke bruto jaarloon ${ }^{4}$ (uitgedrukt in prijzen van 1995) weergegeven per opleidingsniveau en opleidingssector. Over het algemeen kan men stellen dat het loon stijgt naarmate het opleidingsniveau hoger is. Zo blijkt duidelijk dat schoolverlaters zonder enig diploma minder verdienen dan schoolverlaters met een MAVO of VBO diploma. Naast opleidingsniveau zijn er ook verschillen in loon tussen de verschillende onderwijssectoren. Wat onmiddellijk opvalt, is dat ook wat betreft loon schoolverlaters met een technische opleiding weer het meest fortuinlijk zijn. Zowel onder VBO- als MBO- en HBO-ers is het gemiddeld bruto jaarsalaris voor schoolverlaters met een technische achtergrond relatief het hoogst. Voor het VBO en MBO geldt dat degenen uit de sector gezondheidszorg doorgaans het laagste salaris hebben. Bij het HBO is het persoonlijk bruto jaarloon van afgestudeerden van de sector landbouw het laagst. Voor het WO zijn hier geen cijfers gepresenteerd vanwege de geringe aantallen.

In figuur 3.6 is weergegeven wat het gemiddelde beroepsprestige is van schoolverlaters. Het beroepsprestige laat deels een vergelijkbaar beeld zien als het persoonlijk bruto jaarloon. Ook het beroepsprestige loopt op naarmate het opleidingsniveau toeneemt. Ook blijkt dat schoolverlaters uit de sector techniek in alle opleidingsniveaus de meest prestigieuze banen hebben. Het WO vormt hierop een uitzondering. Degenen die in de sector gezondheidszorg zijn afgestudeerd hebben gemiddeld genomen de meest prestigieuze banen. Opvallend is dat binnen het VBO, MBO en HBO schoolverlaters uit de sector gezondheidszorg juist banen hebben met het minste aanzien. Binnen het VBO en MBO blijken ook de schoolverlaters uit de sector landbouw relatief weinig prestigieuze banen te hebben.

4. Voor iedere respondent is het totaal genoten brutosalaris over het enquêtejaar gekoppeld uit het Regionaal Inkomens Onderzoek (RIO). 
Figuur 3.5

Gemiddeld persoonlijk bruto jaarloon (in euro's) van schoolverlaters per opleidingsniveau en opleidingssector (prijspeil 1995)

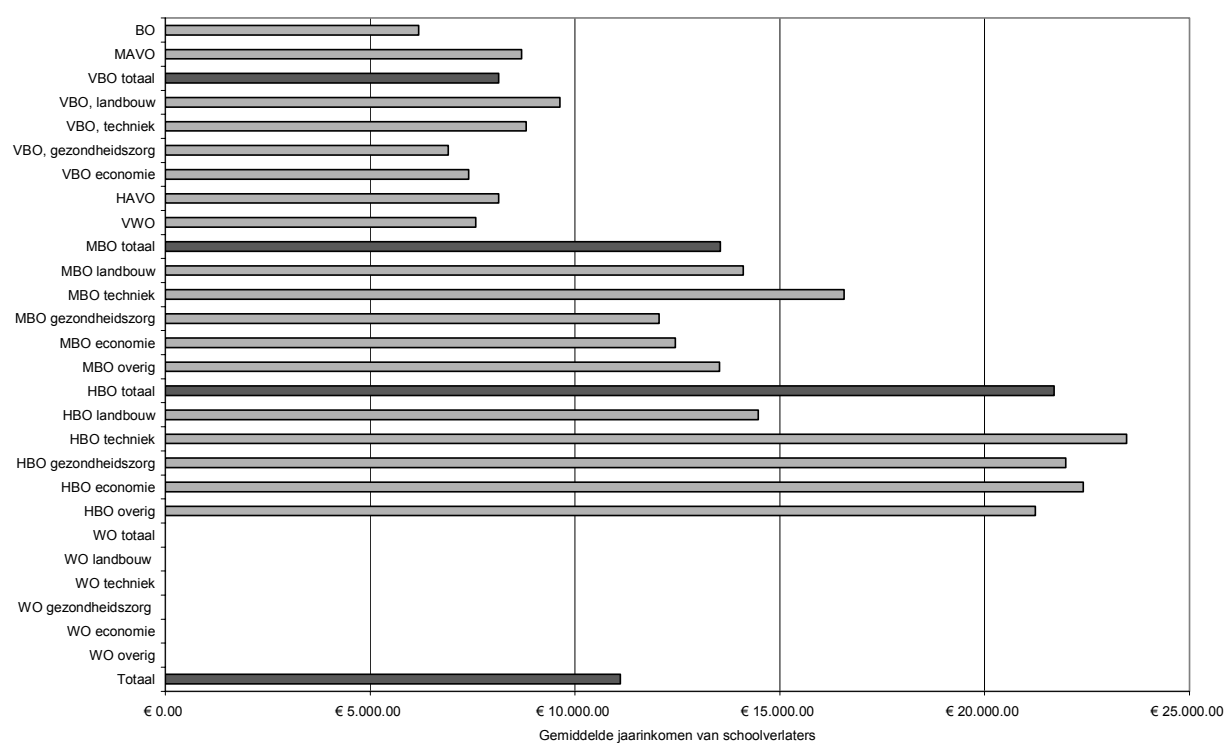

Bron: Schoolverlatersdata VOCL'89; 1994-2003, Regionaal Inkomens Onderzoek 1995-2000, Centraal Bureau voor de Statistiek

Figuur 3.6

Gemiddeld beroepsprestige van schoolverlaters per opleidingsniveau en opleidingssector

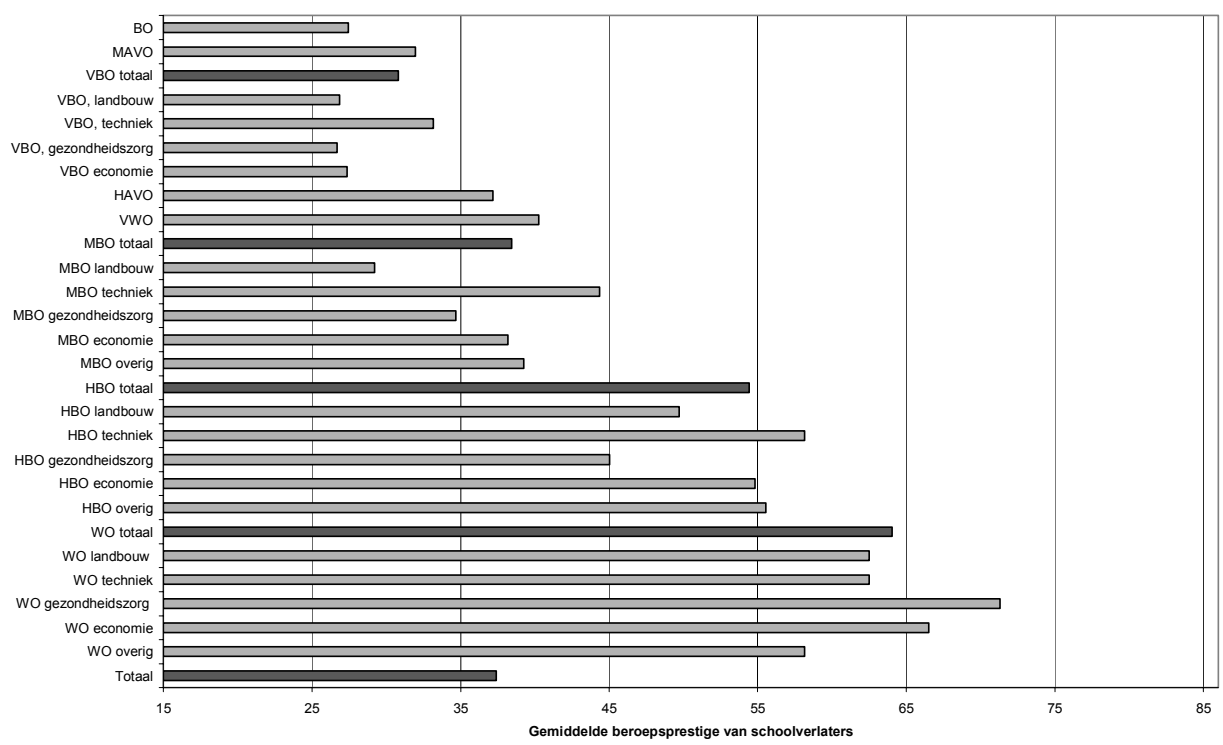

Bron: Schoolverlatersdata VOCL'89, 1994-2003, Centraal Bureau voor de Statistiek

5. Cijfers voor het WO zijn vanwege de geringe aantallen buiten beschouwing gelaten. 



\section{Verklarende analyses}

Bij het verkrijgen van een bepaalde arbeidsmarktpositie door schoolverlaters speelt opleiding een belangrijke rol. Over het hoe en waarom bestaat echter nog aanzienlijke onzekerheid. Is onderwijs belangrijk, omdat er specifieke vaardigheden worden geleerd die later productief worden aangewend of dient onderwijs vooral te onthullen wie over het beste leervermogen beschikt? En hoe belangrijk is de rol van zogeheten 'soft skills' ten opzichte van de meer traditionele hardere indicatoren van menselijk kapitaal?

In dit hoofdstuk gaan we na welke kennis en vaardigheden schuil gaan achter de verschillende diploma's. Centraal hierbij staat de vraag in hoeverre het effect van opleiding op de arbeidsmarktpositie van schoolverlaters kan worden toegeschreven aan kenmerken van leerlingen die al aanwezig waren voor de start van de onderwijsloopbaan dan wel zijn opgedaan gedurende die onderwijsloopbaan. Het gaat daarbij om cognitieve kenmerken (non-verbale intelligentie, schoolprestaties), soft skills (prestatiemotivatie, schoolbeleving) en sociale en culturele hulpbronnen (sociale herkomst, onderwijsondersteunend thuisklimaat). Door middel van multivariate regressie-analyse wordt de afzonderlijke invloed van bovengenoemde kenmerken in kaart gebracht. Daartoe worden verschillende aspecten van de arbeidsmarktpositie van schoolverlaters geanalyseerd. Het gaat om aspecten van kans op werk, werkzekerheid en kwaliteit van het werk.

Eerst wordt echter het hoogst bereikte opleidingsniveau geanalyseerd. Het is belangrijk dit eerst te laten zien omdat op deze manier kan worden aangegeven in hoeverre cognitieve kenmerken, soft skills en sociale en culturele hulpbronnen indirect de arbeidsmarktpositie van schoolverlaters bepalen. Verwacht mag worden dat de genoemde kenmerken van invloed zijn op het opleidingsniveau van schoolverlaters. Het bereikte opleidingsniveau is vervolgens van invloed op de arbeidsmarktpositie van schoolverlaters. Schoolverlaters die een hoog opleidingsniveau bereiken hebben een betere positie op de arbeidsmarkt dan schoolverlaters die een lager opleidingsniveau bereiken.

\subsection{Bereikt opleidingsniveau}

Om het behaalde opleidingsniveau te analyseren zijn drie modellen gebruikt. Het basismodel bevat het intercept en de regressiecoëfficiënten van sekse en etniciteit. Het intercept laat hier het gemiddelde behaalde opleidingsniveau (uitgedrukt in jaren scholing, zie voor een beschrijving bijlage 3) voor mannelijke, autochtone schoolverlaters zien. Deze bedraagt 12,1 jaren, wat overeenkomt met het KMBOniveau. Daarnaast blijkt dat sekse en etniciteit een significante invloed hebben op het behaalde opleidingsniveau van schoolverlaters. De regressiecoëfficiënt bij sekse is voor vrouwen significant positief. Dit geeft aan dat vrouwelijke schoolverlaters gemiddeld genomen een hoger opleidingsniveau behalen dan mannelijke schoolverlaters. Het hoogst behaalde diploma van vrouwelijke schoolverlaters, uitgedrukt in jaren scholing, is gemiddeld ongeveer één jaar hoger dan voor 
mannelijke schoolverlaters. Allochtone schoolverlaters behalen gemiddeld een lager opleidingsniveau dan autochtone schoolverlaters. Hier geldt dat het hoogst behaalde opleidingsniveau van allochtone schoolverlaters, uitgedrukt in jaren scholing, gemiddeld ongeveer 1,3 jaar lager is dan van autochtone schoolverlaters.

In model 2 zijn de cognitieve kenmerken, soft skills en sociale en culturele hulpbronnen van schoolverlaters toegevoegd aan het model. Allereerst blijkt uit model 2 dat de invloed van sekse op het behaalde opleidingsniveau weinig is veranderd in vergelijking met model 1 . De gevonden verschillen tussen mannelijke en vrouwelijke schoolverlaters kunnen daarom niet worden toegeschreven aan de toegevoegde variabelen. De verschillen tussen allochtone en autochtone schoolverlaters zijn daarentegen wel behoorlijk afgenomen. De gevonden verschillen tussen allochtone en autochtone schoolverlaters kunnen daarmee voor een groot deel worden toegeschreven aan verschillen in cognitieve kenmerken, soft skills en sociale en culturele hulpbronnen.

Daarnaast blijkt uit model 2 dat schoolprestaties en non-verbale intelligentie een significant positieve invloed hebben op het behaalde opleidingsniveau. Schoolverlaters die hoger scoren op de CITO entree toetsen behalen een hoger opleidingsniveau dan schoolverlaters die hier lager op scoren. Bovendien geldt dat schoolverlaters een hoger opleidingsniveau bereiken als ze over meer non-verbale intelligentie beschikken. Ook de mate waarin leerlingen gemotiveerd zijn (prestatiemotivatie) en de mate waarin school 'leuk' wordt gevonden (schoolbeleving) dragen in positieve zin bij aan een succesvolle onderwijsloopbaan. Schoolverlaters met meer prestatiemotivatie bereiken een hoger opleidingsniveau dan schoolverlaters met minder prestatiemotivatie en schoolverlaters met een hoge schoolbeleving bereiken een hoger opleidingsniveau dan schoolverlaters met een lagere schoolbeleving.

Verder speelt het opleidingsniveau, de maatschappelijke positie en culturele participatie van de ouders en het onderwijsondersteunend thuisklimaat een rol bij het behaalde opleidingsniveau van schoolverlaters. Ten eerste geldt dat schoolverlaters met hoog opgeleide ouders een hoger opleidingsniveau behalen dan schoolverlaters met laag opgeleide ouders. Ten tweede blijkt dat schoolverlaters een hoger opleidingsniveau bereiken wanneer de ouders zelf werkzaam zijn in vergelijking met schoolverlaters waarvan de ouders niet werkzaam zijn. Dit geldt met name voor schoolverlaters waarvan de ouders werkzaam zijn als zelfstandige zonder personeel of werken als middelbare of hogere employee. Ten derde komt naar voren dat schoolverlaters met ouders waarvan de culturele participatie hoog is een hoger opleidingsniveau bereiken dan schoolverlaters van wie de ouders nauwelijks aan culturele participatie doen. Ten vierde blijkt dat onderwijsondersteunend gedrag van de ouders leidt tot betere schoolprestaties van de kinderen. Schoolverlaters waarvan de ouders vaker praten over school(prestaties) of vaker complimenten geven, bereiken een hoger opleidingsniveau dan schoolverlaters waarvan de ouders dit minder vaak doen. 
Tabel 4.1

Resultaten van de analyse van het hoogst behaalde opleidingsniveau: ongestandaardiseerde regressiecoëfficiënten $(N=10.123)$

\begin{tabular}{|c|c|c|c|}
\hline & Model 1 & Model 2 & Model 3 \\
\hline Intercept & $12,056^{\star *}$ & $6,652^{\star *}$ & $1,782^{* *}$ \\
\hline \multicolumn{4}{|l|}{ Sekse } \\
\hline Man (ref.) & - & - & - \\
\hline Vrouw & $0,954^{\star *}$ & $0,876^{\star \star}$ & $0,690^{*}$ \\
\hline \multicolumn{4}{|l|}{ Etniciteit } \\
\hline Autochtoon (ref.) & - & - & - \\
\hline Allochtoon & $-1,291^{* *}$ & $-0,445^{\star *}$ & $-0,595^{\star *}$ \\
\hline Schoolprestaties & & $4,222^{* *}$ & $2,107^{\star *}$ \\
\hline Non-verbale intelligentie & & $0,659^{* *}$ & $0,415^{\star *}$ \\
\hline Prestatiemotivatie & & $0,759^{* *}$ & $0,751^{* *}$ \\
\hline Schoolbeleving & & $0,570^{* *}$ & $0,481^{* *}$ \\
\hline Opleidingsniveau ouders & & $0,129^{\star *}$ & $0,088^{* *}$ \\
\hline \multicolumn{4}{|l|}{ Maatschappelijke positie ouders } \\
\hline Niet werkzaam (ref.) & & - & - \\
\hline Arbeider & & $0,287^{* *}$ & $0,386^{* *}$ \\
\hline Zelfstandige zonder personeel & & $0,689^{\star *}$ & $0,693^{\star *}$ \\
\hline Zelfstandige met personeel & & $0,490^{* *}$ & $0,450^{* *}$ \\
\hline Lagere employee & & $0,446^{* *}$ & $0,405^{\star *}$ \\
\hline Middelbare employee & & $0,625^{\star *}$ & $0,580^{\star *}$ \\
\hline Hogere employee & & $0,679^{* *}$ & $0,524^{\star *}$ \\
\hline Culturele participatie ouders & & $0,371^{* *}$ & $0,264^{*}$ \\
\hline Leesgedrag ouders & & $-0,057$ & $-0,133$ \\
\hline Onderwijsondersteunend thuisklimaat & & $0,668^{\star *}$ & $0,586^{\star *}$ \\
\hline Schooladvies & & & $0,975^{\star *}$ \\
\hline Aangepaste $\mathrm{R}^{2}$ & 0,035 & 0,269 & 0,310 \\
\hline
\end{tabular}

${ }^{* *} p<0,01 ;{ }^{*} p<0,05$

ref. $=$ referentiecategorie

Bron: Schoolverlatersdata VOCL'89, 1994-2003, Centraal Bureau voor de Statistiek

In model 3 is het schooladvies van schoolverlaters toegevoegd. Dit advies is gebaseerd op de prestaties van de leerling in het basisonderwijs, de score op de CITO eindtoets en het beeld dat de docent(e) heeft van de capaciteiten van de leerling. Het is dan ook niet vreemd dat de invloed van cognitieve kenmerken, soft skills en sociale en culturele hulpbronnen in model 3 is gedaald in vergelijking met model 2. Dit geldt met name voor schoolprestaties, waar de invloed op het behaalde opleidingsniveau ongeveer is gehalveerd. Schooladvies zelf heeft zoals verwacht een positieve invloed op het behaalde opleidingsniveau. Overigens wijst de vergelijking van cognitieve kenmerken, soft skills en sociale en culturele hulpbronnen uit dat het schooladvies de grootste invloed heeft op het uiteindelijk behaalde opleidingsniveau van schoolverlaters. Van het advies dat de leerling heeft meegekregen met betrekking tot het voortgezet onderwijs mag ook worden verwacht dat het een goede voorspeller is van het uiteindelijk bereikte opleidingsniveau, aangezien dit advies, zoals eerder gezegd, is gebaseerd op de prestaties in het basisonderwijs en de score op de CITO eindtoets. De indicator 'schoolprestaties' heeft daarna de grootste invloed op het behaalde opleidingsniveau, gevolgd door prestatiemotivatie, schoolbeleving en vervolgens non-verbale intelligentie. Van de sociale en culturele hulpbronnen heeft het opleidingsniveau van de ouders de 
sterkste invloed, gevolgd door maatschappelijke positie, onderwijsondersteunend gedrag en culturele participatie.

\subsection{Werkzame beroepsbevolking}

In tabel 4.2 staan weergegeven de resultaten met betrekking tot de kans tot de werkzame beroepsbevolking ${ }^{6}$ te behoren. Deze zijn gebaseerd op logistische regressie-analyse. Tabel 4.2 laat zien dat het hoogst bereikte opleidingsniveau van schoolverlaters een positief effect heeft op de kans om tot de werkzame beroepsbevolking te behoren.

Volgens model 1 bedraagt het logit effect 0,145. Omgerekend in termen van odds ratio's is de kansverhouding van werk tegenover geen werk voor de hoogst opgeleide schoolverlaters bijna zeven keer groter dan de overeenkomstige kansverhouding voor de laagst opgeleide schoolverlaters $\left(e^{\left(13^{*} 0,145\right)}=6,586\right)$.

De invloed van het hoogst bereikte opleidingsniveau op de kans op werk is een stuk lager na controle voor sekse, etniciteit en opleidingsrichting. Nu bedraagt het geschatte logit effect 0,106. Daarnaast wordt het effect van aanvullende scholing hier significant. Schoolverlaters die na het behalen van de hoogst bereikte opleiding nog voor ten minste twee jaar een andere opleiding hebben gevolgd in het initiële onderwijs, maar deze niet met een diploma hebben afgerond, hebben een grotere kans om werkzaam te zijn dan degenen zonder aanvullende scholing. Blijkbaar wordt deze aanvullende scholing door werkgevers toch gewaardeerd, ondanks het feit dat er geen diploma van is behaald. Verder hebben allochtone schoolverlaters een geringere kans om werkzaam te zijn dan autochtone schoolverlaters. Ook is opleidingsrichting van belang. Schoolverlaters van de richtingen landbouw, techniek, gezondheidszorg, economie en overig hebben een grotere kans op werk dan schoolverlaters die alleen algemeen vormend onderwijs hebben voltooid. Verder hebben schoolverlaters die in de Randstad wonen een even grote kans op werk als schoolverlaters uit andere regio's van Nederland.

De kans op werk wordt voor schoolverlaters bepaald door verschillende kenmerken die al aanwezig waren voorafgaand aan de start van de onderwijsloopbaan. Ten eerste is non-verbale intelligentie van belang bij de kans om werkzaam te zijn. Naarmate schoolverlaters beschikken over een hoger IQ, des te groter is hun kans op werk. Tevens doet de maatschappelijke positie van de ouders ertoe. Schoolverlaters waarvan de ouders werkzaam zijn als arbeider, zelfstandige met personeel, lager of middelbare employee hebben een grotere kans op werk dan degenen waarvan de ouders niet werkzaam zijn. Een laatste noemenswaardig resultaat is dat het effect van het hoogst bereikte opleidingsniveau van schoolverlaters verder is gedaald. Na toevoeging van cognitieve kenmerken, soft skills en ouderlijke hulpbronnen is het effect van het hoogst bereikte opleidingsniveau 0,070 . Dit effect daalt nog iets verder, wanneer rekening wordt gehouden met de

6. In dit geval is de werkzame beroepsbevolking geoperationaliseerd als $100 \%$ - het aandeel werklozen in de populatie. 
invloed van het schooladvies voor het voortgezet onderwijs. Het schooladvies is overigens zelf niet significant als het gaat om de kans op werk.

Tabel 4.2

Resultaten van de analyse van de kans tot de werkzame beroepsbevolking te behoren: logit effecten ( $N=8.699$ )

\begin{tabular}{|c|c|c|c|c|}
\hline & Model 1 & Model 2 & Model 3 & Model 4 \\
\hline Intercept & $1,234^{\star *}$ & $1,472^{\star *}$ & 0,517 & 0,233 \\
\hline Opleidingsniveau & $0,145^{\star *}$ & $0,106^{\star *}$ & $0,070^{* *}$ & $0,064^{*}$ \\
\hline Aanvullende scholing zonder diploma & 0,211 & $0,371^{*}$ & $0,360^{*}$ & $0,363^{*}$ \\
\hline Studievertraging & 0,056 & 0,039 & 0,028 & 0,025 \\
\hline \multicolumn{5}{|l|}{ Sekse } \\
\hline Man (ref.) & & - & - & - \\
\hline Vrouw & & $-0,221$ & $-0,243^{*}$ & $-0,249^{*}$ \\
\hline \multicolumn{5}{|l|}{ Etniciteit } \\
\hline Autochtoon (ref.) & & - & - & - \\
\hline Allochtoon & & $-0,800^{* *}$ & $-0,636^{\star *}$ & $-0,642^{* *}$ \\
\hline \multicolumn{5}{|l|}{ Opleidingsrichting } \\
\hline Algemeen (ref.) & & - & - & - \\
\hline Landbouw & & $0,852^{*}$ & $1,000^{*}$ & $1,035^{\star}$ \\
\hline Techniek & & $0,830^{* *}$ & $0,910^{* *}$ & $0,948^{* *}$ \\
\hline Economie & & $0,384^{*}$ & $0,472^{* *}$ & $0,500^{* *}$ \\
\hline Gezondheidszorg & & $0,335^{*}$ & $0,464^{\star *}$ & $0,504^{\star *}$ \\
\hline Overig & & $0,523^{*}$ & $0,647^{*}$ & $0,678^{* *}$ \\
\hline \multicolumn{5}{|l|}{ Regio } \\
\hline Randstad & & 0,133 & 0,139 & $-0,132$ \\
\hline Overig (ref.) & & - & - & - \\
\hline Schoolprestaties & & & 0,198 & 0,111 \\
\hline Non-verbale intelligentie & & & $0,577^{*}$ & $0,565^{\star}$ \\
\hline Prestatiemotivatie & & & 0,239 & 0,241 \\
\hline Schoolbeleving & & & 0,311 & 0,306 \\
\hline Opleidingsniveau ouders & & & 0,032 & 0,030 \\
\hline \multicolumn{5}{|l|}{ Maatschappelijke positie ouders } \\
\hline Niet werkzaam (ref.) & & & - & - \\
\hline Arbeider & & & $0,448^{* *}$ & $0,451^{\star *}$ \\
\hline Zelfstandige zonder personeel & & & 0,462 & 0,462 \\
\hline Zelfstandige met personeel & & & $0,705^{*}$ & $0,704^{*}$ \\
\hline Lagere employee & & & $0,504^{*}$ & $0,503^{*}$ \\
\hline Middelbare employee & & & $0,426^{*}$ & $0,426^{*}$ \\
\hline Hogere employee & & & 0,092 & 0,086 \\
\hline Culturele participatie ouders & & & $-0,309$ & $-0,310$ \\
\hline Leesgedrag ouders & & & 0,045 & 0,044 \\
\hline Onderwijsondersteunend thuisklimaat & & & 0,315 & 0,313 \\
\hline Schooladvies & & & & 0,060 \\
\hline Model $\mathrm{Chi}^{2}$ & $84,191^{* *}$ & $156,904^{\star *}$ & $197,438^{* *}$ & $197,946^{\star *}$ \\
\hline Df & 3 & 11 & 25 & 26 \\
\hline
\end{tabular}


Tabel 4.3

Resultaten van de analyse van de kans op vast werk: logit effecten $(\mathrm{N}=8.818)$

\begin{tabular}{|c|c|c|c|c|}
\hline & Model 1 & Model 2 & Model 3 & Model 4 \\
\hline Intercept & $0,622^{* *}$ & $0,648^{\star *}$ & $0,470^{*}$ & $0,808^{* *}$ \\
\hline Opleidingsniveau & $0,097^{* *}$ & $0,081^{* *}$ & $0,076^{\star *}$ & $0,083^{* *}$ \\
\hline Aanvullende scholing zonder diploma & $-0,099$ & $-0,009$ & $-0,007$ & $-0,010$ \\
\hline Studievertraging & 0,059 & 0,067 & 0,072 & 0,075 \\
\hline \multicolumn{5}{|l|}{ Sekse } \\
\hline Man (ref.) & & - & - & - \\
\hline Vrouw & & 0,025 & 0,010 & 0,015 \\
\hline \multicolumn{5}{|l|}{ Etniciteit } \\
\hline Autochtoon (ref.) & & - & - & - \\
\hline Allochtoon & & $-0,682^{* *}$ & $-0,617^{* *}$ & $-0,611^{* *}$ \\
\hline \multicolumn{5}{|l|}{ Opleidingsrichting } \\
\hline Algemeen (ref.) & & - & - & - \\
\hline Landbouw & & $0,528^{*}$ & $0,512^{*}$ & $0,469^{*}$ \\
\hline Techniek & & $0,420^{* *}$ & $0,421^{* *}$ & $0,374^{* *}$ \\
\hline Economie & & 0,137 & 0,138 & 0,105 \\
\hline Gezondheidszorg & & 0,118 & 0,136 & 0,090 \\
\hline Overig & & 0,228 & 0,266 & 0,229 \\
\hline \multicolumn{5}{|l|}{ Regio } \\
\hline Randstad & & 0,114 & 0,114 & 0,121 \\
\hline Overig (ref.) & & - & - & - \\
\hline Schoolprestaties & & & 0,069 & 0,177 \\
\hline Non-verbale intelligentie & & & 0,226 & 0,240 \\
\hline Prestatiemotivatie & & & 0,117 & 0,115 \\
\hline Schoolbeleving & & & 0,053 & 0,056 \\
\hline Opleidingsniveau ouders & & & $-0,021$ & $-0,019$ \\
\hline \multicolumn{5}{|l|}{ Maatschappelijke positie ouders } \\
\hline Niet werkzaam (ref.) & & & - & - \\
\hline Arbeider & & & $0,224^{*}$ & $0,219^{*}$ \\
\hline Zelfstandige zonder personeel & & & $0,621^{* *}$ & $0,620^{* *}$ \\
\hline Zelfstandige met personeel & & & 0,246 & 0,247 \\
\hline Lagere employee & & & 0,235 & 0,236 \\
\hline Middelbare employee & & & $0,353^{* *}$ & $0,353^{* *}$ \\
\hline Hogere employee & & & $0,296^{*}$ & $0,301^{*}$ \\
\hline Culturele participatie ouders & & & $-0,349^{* *}$ & $-0,349^{* *}$ \\
\hline Leesgedrag ouders & & & 0,066 & 0,069 \\
\hline Onderwijsondersteunend thuisklimaat & & & $0,242^{*}$ & $0,245^{*}$ \\
\hline Schooladvies & & & & $-0,071$ \\
\hline Model Chi ${ }^{2}$ & $101,671^{* *}$ & $173,952^{\star *}$ & $209,672^{\star *}$ & $211,576^{\star *}$ \\
\hline Df & 3 & 11 & 25 & 26 \\
\hline
\end{tabular}

${ }^{* *} p<0,01 ;{ }^{*} p<0,05$

ref. $=$ referentiecategorie

Bron: Schoolverlatersdata VOCL'89, 1994-2003, Centraal Bureau voor de Statistiek

\subsection{Vast werk}

Uit de analyse van de kans op vast werk komt naar voren dat werkzame schoolverlaters die een hoog opleidingsniveau hebben bereikt, vaker een vaste aanstelling hebben dan degenen met een laag opleidingsniveau. Per jaar extra scholing neemt de geschatte kansverhouding met 10 procent toe $\left(e^{0,097}=1,101\right)$. Een deel van dit opleidingseffect worden toegeschreven aan de kenmerken sekse, etniciteit en opleidingsrichting. Wanneer rekening wordt gehouden met deze 
kenmerken dan daalt het logit effect van 0,097 naar 0,081. Etniciteit heeft een negatief effect op de kans op vast werk. Allochtonen zijn aanmerkelijk vaker in een tijdelijk dienstverband werkzaam dan autochtonen. Daarnaast is de gevolgde opleidingsrichting van invloed op de kans op vast werk. Schoolverlaters van de richtingen landbouw en techniek hebben vaker een vaste baan dan degenen, die alleen algemeen vormend onderwijs hebben behaald.

De maatschappelijke positie van de ouders is bepalend voor de kans op vast werk. Schoolverlaters uit een gezin waarvan de ouders in welke beroepsklasse dan ook werkzaam zijn - uitgezonderd die van zelfstandigen met personeel en lagere employees -, hebben een grotere kans op een vaste baan dan schoolverlaters uit een gezin waarvan de ouders niet werkzaam zijn. Ook het onderwijsondersteunend thuisklimaat heeft een positieve invloed op de kans vast werk te vinden. De culturele hulpbronnen van de ouders hebben daarentegen een negatief effect op de kans op vast werk. Naarmate de ouders vaker participeren in culturele activiteiten, is de kans op een vaste baan geringer.

\subsection{Baan naar niveau en richting}

Een baan die qua niveau aansluit bij het behaalde opleidingsniveau is een belangrijke indicator voor de kwaliteit van de gevonden baan. Voor schoolverlaters die de arbeidsmarkt betreden is het vaak echter niet eenvoudig een passende baan te vinden. Schoolverlaters die de arbeidsmarkt betreden, moeten concurreren om de beschikbare banen met degenen die zich al op de arbeidsmarkt bevinden en over meer werkervaring beschikken. Dit kan voor schoolverlaters leiden tot werkloosheid of het accepteren van een baan beneden het bereikte opleidingsniveau. Tabel 4.4 vermeldt de resultaten van de analyse van de kans op een baan die aansluit op het bereikte opleidingsniveau. Uit deze tabel blijkt dat schoolverlaters van een hoog opleidingsniveau minder vaak een baan vinden die aansluit bij het behaalde opleidingsniveau dan schoolverlaters van een laag opleidingsniveau. Dit is niet vreemd wanneer je bedenkt dat er voor de laagst opgeleiden (dat wil zeggen degenen met alleen basisonderwijs) geen banen zijn van een lager niveau. Voor schoolverlaters met alleen basisonderwijs bestaat daardoor niet de mogelijkheid uit te wijken naar een baan onder hun niveau. Hoger opgeleide schoolverlaters kunnen daarentegen wel uitwijken naar een baan beneden het bereikte opleidingsniveau. Verder heeft aanvullende scholing zonder diploma een positief significante invloed. Dit geeft aan dat schoolverlaters die na afronding van de opleiding nog meer dan één jaar aanvullend onderwijs hebben gevolgd zonder daarbij een diploma te behalen, een grotere kans hebben een baan te vinden die aansluit bij het eerder bereikte opleidingsniveau dan schoolverlaters die direct na afronding van de hoogst behaalde opleiding zijn toegetreden tot de arbeidsmarkt. 
Tabel 4.4

Resultaten van analyse van de kans op een baan die aansluit bij het behaalde opleidingsniveau: logit effecten $(N=8.052)$

\begin{tabular}{|c|c|c|c|c|}
\hline & Model 1 & Model 2 & Model 3 & Model 4 \\
\hline Intercept & $3,236^{\star *}$ & $3,216^{\star *}$ & $3,004^{* *}$ & $2,799^{* *}$ \\
\hline Opleidingsniveau & $-0,219^{* *}$ & $-0,222^{\star *}$ & $-0,247^{\star *}$ & $-0,253^{\star *}$ \\
\hline Aanvullende scholing zonder diploma & $0,411^{* *}$ & $0,466^{* *}$ & $0,452^{* *}$ & $0,451^{* *}$ \\
\hline Studievertraging & 0,088 & 0,010 & 0,012 & 0,012 \\
\hline \multicolumn{5}{|l|}{ Sekse } \\
\hline Man (ref.) & & - & - & - \\
\hline Vrouw & & 0,111 & 0,115 & 0,112 \\
\hline \multicolumn{5}{|l|}{ Etniciteit } \\
\hline Autochtoon (ref.) & & - & - & - \\
\hline Allochtoon & & $-0,137$ & $-0,116$ & $-0,118$ \\
\hline \multicolumn{5}{|l|}{ Opleidingsrichting } \\
\hline Algemeen (ref.) & & - & - & - \\
\hline Landbouw & & $-0,973^{* *}$ & $-0,848^{* *}$ & $-0,821^{* *}$ \\
\hline Techniek & & $0,570^{\star *}$ & $0,653^{* *}$ & $0,681^{* *}$ \\
\hline Economie & & $-0,417^{* *}$ & $-0,352^{* *}$ & $-0,331^{* *}$ \\
\hline Gezondheidszorg & & $-0,542^{* *}$ & $-0,448^{* *}$ & $-0,420^{* *}$ \\
\hline Overig & & $0,436^{\star *}$ & $0,506^{\star *}$ & $0,530^{* *}$ \\
\hline \multicolumn{5}{|l|}{ Regio } \\
\hline Randstad & & $0,168^{* *}$ & $0,154^{\star *}$ & $0,150^{\star *}$ \\
\hline Overig (ref.) & & - & - & - \\
\hline Schoolprestaties & & & 0,173 & 0,106 \\
\hline Non-verbale intelligentie & & & 0,161 & 0,153 \\
\hline Prestatiemotivatie & & & 0,132 & 0,134 \\
\hline Schoolbeleving & & & 0,143 & 0,142 \\
\hline Opleidingsniveau ouders & & & 0,008 & 0,007 \\
\hline \multicolumn{5}{|l|}{ Maatschappelijke positie ouders } \\
\hline Niet werkzaam (ref.) & & & - & - \\
\hline Arbeider & & & $-0,096$ & $-0,092$ \\
\hline Zelfstandige zonder personeel & & & $-0,246$ & $-0,244$ \\
\hline Zelfstandige met personeel & & & 0,074 & 0,075 \\
\hline Lagere employee & & & $-0,117$ & $-0,117$ \\
\hline Middelbare employee & & & $-0,092$ & $-0,091$ \\
\hline Hogere employee & & & 0,085 & 0,083 \\
\hline Culturele participatie ouders & & & 0,057 & 0,057 \\
\hline Leesgedrag ouders & & & 0,103 & 0,101 \\
\hline Onderwijsondersteunend thuisklimaat & & & 0,128 & 0,126 \\
\hline Schooladvies & & & & 0,045 \\
\hline Model Chi ${ }^{2}$ & $849,752^{* *}$ & $1.206,274^{\star *}$ & $1.237,626^{\star *}$ & $1.238,747^{* *}$ \\
\hline Df & 3 & 11 & 25 & 26 \\
\hline
\end{tabular}

${ }^{* *} p<0,01 ;{ }^{*} p<0,05$

ref. $=$ referentiecategorie

Bron: Schoolverlatersdata VOCL'89, 1994-2003, Centraal Bureau voor de Statistiek

Wanneer vervolgens wordt gecorrigeerd voor sekse, etniciteit en gevolgde opleidingsrichting neemt de invloed van aanvullende scholing zonder diploma op de kans op een baan op niveau iets toe. Verder blijkt dat er verschillen bestaan tussen de opleidingsrichtingen in de kans een baan op niveau te vinden. Schoolverlaters van de richting techniek en de richting overig vinden vaker een baan die aansluit bij het bereikte opleidingsniveau dan schoolverlaters die vanuit een algemeen vormende opleiding de arbeidsmarkt betreden. Daarentegen hebben schoolverlaters 
die een opleiding in de richting landbouw, economie of gezondheidszorg hebben gevolgd een kleinere kans een baan op niveau te vinden dan schoolverlaters die een opleiding in een algemene richting hebben gevolgd. Sekse en etniciteit hebben verder geen invloed op de kans een baan te vinden die aansluit bij het bereikte opleidingsniveau. Mannen vinden even vaak als vrouwen en allochtonen even vaak als autochtonen een baan op niveau. Dit laatste is vrij opmerkelijk. Eerder is naar voren gekomen dat de kans op (vast) werk voor allochtonen kleiner is dan voor autochtonen, ook als rekening wordt gehouden met het behaalde opleidingsniveau, cognitieve kenmerken, soft skills en sociale en culturele hulpbronnen. Voor de kans op het vinden van een baan op niveau geldt dit echter niet. Met andere woorden: wanneer er eenmaal sprake is van (vast) werk, dan wordt er geen verschil meer waargenomen tussen allochtone en autochtone schoolverlaters in de kans op het vinden van een baan die aansluit bij het behaalde opleidingsniveau. Tot slot blijkt dat de regio waar schoolverlaters wonen van invloed is op de kans een baan te vinden die aansluit bij het behaalde opleidingsniveau. Schoolverlaters die in de Randstad wonen, vinden vaker een baan op niveau dan schoolverlaters uit andere regio's van Nederland.

Cognitieve kenmerken, soft skills en sociale en culturele hulpbronnen hebben verder geen significante invloed op de kans een baan op een baan op niveau. Hetzelfde geldt voor schooladvies.

Werkzoekenden beschikken over meerdere arbeidsaanpassingsinstrumenten om een baan te vinden indien de arbeidsmarkt ruim is. Naast het accepteren van een baan beneden het behaalde opleidingsniveau kunnen schoolverlaters bijvoorbeeld kiezen voor een baan buiten de gevolgde opleidingsrichting of beneden het gewenste aantal uren. Uit de analyse van de kans een baan te vinden die aansluit bij de gevolgde opleidingsrichting blijkt allereerst dat aanvullende scholing zonder diploma een negatieve invloed heeft op de kans een baan te vinden die qua richting aansluit bij de gevolgde richting. Schoolverlaters die na het behalen van het diploma nog minimaal één jaar verder zijn gaan leren zonder een diploma te hebben behaald vinden gemiddeld minder vaak een baan die aansluit bij de gevolgde opleidingsrichting. Dit komt wellicht omdat een deel van de schoolverlaters in een andere richting verder is gaan leren dan de richting waarin ze het hoogste diploma hebben behaald. Deze schoolverlaters hebben waarschijnlijk een baan gevonden die aansluit bij de richting waarin ze verder zijn gaan leren. Daarnaast blijkt dat sekse, etniciteit en gevolgde opleidingsrichting van invloed zijn op de kans een baan te vinden die aansluit bij de gevolgde opleidingsrichting. Vrouwen hebben minder vaak een baan die aansluit bij de gevolgde opleidingsrichting dan mannen. Allochtonen hebben minder vaak dan autochtonen een baan gevonden die qua richting aansluit bij de gevolgde opleiding. Verder geldt dat schoolverlaters van de opleidingsrichtingen techniek, economie en de overige richtingen vaker een baan hebben gevonden die past bij de gevolgde opleidingsrichting dan schoolverlaters van de richting landbouw. En schoolverlaters van de opleidingsrichting gezondheidszorg hebben het minst vaak een baan in de eigen richting gevonden. Schooladvies heeft een significante invloed op het vinden van een baan die aansluit bij de gevolgde opleidingsrichting. Schoolverlaters met een hoog schooladvies vinden minder vaak een baan die 
aansluit bij de gevolgde opleidingsrichting dan schoolverlaters met een lager schooladvies. De oorzaak hiervan is niet duidelijk.

Tabel 4.5

Resultaten van de analyse van de kans op een baan die aansluit bij de gevolgde opleidingsrichting: logit effecten $(\mathrm{N}=6.146)$

\begin{tabular}{|c|c|c|c|c|}
\hline & Model 1 & Model 2 & Model 3 & Model 4 \\
\hline Intercept & $0,502^{* *}$ & 0,124 & $-0,057$ & 0,374 \\
\hline Opleidingsniveau & $-0,011$ & $-0,023$ & $-0,027$ & $-0,011$ \\
\hline Aanvullende scholing zonder diploma & $-0,318^{\star *}$ & $-0,384^{\star *}$ & $-0,393^{\star *}$ & $-0,384^{* *}$ \\
\hline Studievertraging & 0,064 & $-0,074$ & $-0,069$ & $-0,071$ \\
\hline \multicolumn{5}{|l|}{ Sekse } \\
\hline Man (ref.) & & - & - & - \\
\hline Vrouw & & $-0,138$ & $-0,153^{*}$ & $0,146^{*}$ \\
\hline \multicolumn{5}{|l|}{ Etniciteit } \\
\hline Autochtoon (ref.) & & - & - & - \\
\hline Allochtoon & & $-0,300^{\star *}$ & $-0,296^{\star *}$ & $-0,292^{* *}$ \\
\hline \multicolumn{5}{|l|}{ Opleidingsrichting } \\
\hline Landbouw (ref.) & & - & - & - \\
\hline Techniek & & $0,988^{* *}$ & $0,984^{* *}$ & $0,986^{* *}$ \\
\hline Economie & & $1,417^{\star *}$ & $1,415^{\star *}$ & $1,434^{\star *}$ \\
\hline Gezondheidszorg & & $-0,502^{* *}$ & $-0,504^{* *}$ & $-0,506^{* *}$ \\
\hline Overig & & $0,878^{\star *}$ & $0,880^{\star *}$ & $0,888^{\star *}$ \\
\hline \multicolumn{5}{|l|}{ Regio } \\
\hline Randstad & & $-0,092$ & $-0,085$ & $-0,077$ \\
\hline Overig (ref.) & & - & - & - \\
\hline Schoolprestaties & & & $-0,047$ & 0,112 \\
\hline Non-verbale intelligentie & & & 0,130 & 0,147 \\
\hline Prestatiemotivatie & & & 0,191 & 0,185 \\
\hline Schoolbeleving & & & 0,132 & 0,132 \\
\hline Opleidingsniveau ouders & & & 0,004 & 0,006 \\
\hline \multicolumn{5}{|l|}{ Maatschappelijke positie ouders } \\
\hline Niet werkzaam (ref.) & & & - & - \\
\hline Arbeider & & & $-0,004$ & $-0,014$ \\
\hline Zelfstandige zonder personeel & & & 0,063 & 0,057 \\
\hline Zelfstandige met personeel & & & 0,041 & 0,037 \\
\hline Lagere employee & & & $-0,043$ & $-0,044$ \\
\hline Middelbare employee & & & 0,001 & 0,000 \\
\hline Hogere employee & & & $-0,026$ & $-0,024$ \\
\hline Culturele participatie ouders & & & 0,115 & 0,117 \\
\hline Leesgedrag ouders & & & $-0,171$ & $-0,165$ \\
\hline Onderwijsondersteunend thuisklimaat & & & 0,059 & 0,063 \\
\hline Schooladvies & & & & $-0,112^{*}$ \\
\hline Model $\mathrm{Chi}^{2}$ & $13,021^{*}$ & $776,977^{* *}$ & $789,537^{\star *}$ & $795,223^{* *}$ \\
\hline Df & & 10 & 24 & 25 \\
\hline
\end{tabular}

${ }^{* *} p<0,01 ;{ }^{*} p<0,05$

ref. $=$ referentiecategorie

Bron: Schoolverlatersdata VOCL'89, 1994-2003, Centraal Bureau voor de Statistiek

\subsection{Beroepsprestige}

Het hoogst bereikte opleidingsniveau heeft, net als bij de andere arbeidsmarktkenmerken, een positieve invloed op het beroepsprestige. leder jaar extra scholing levert 2,8 extra prestigepunten op. Dit betekent dat er een verschil van ongeveer 36 
punten is tussen de laagst en hoogst opgeleide schoolverlaters. Daarnaast heeft aanvullende scholing zonder diploma een positief effect op het beroepsprestige van de gevonden baan. Schoolverlaters die na het hoogst bereikte niveau nog aanvullende scholing hebben gevolgd in het initiële onderwijs, maar daarvan geen diploma hebben behaald, oefenen een beroep uit dat 2,9 prestigepunten meer waard is dan schoolverlaters die geen aanvullende scholing hebben gevolgd. Ook is studievertraging van belang. Schoolverlaters die tijdens de hoogst bereikte opleiding studievertraging hebben opgelopen, bereiken een beroep dat meer prestige oplevert dan schoolverlaters die geen vertraging hebben opgelopen. Het is mogelijk dat deze vertraging het gevolg is van buitenschoolse activiteiten (stage in het buitenland, bestuurswerkzaamheden bij studentenvereniging), die veelal een positief effect hebben op de arbeidsmarktpositie van schoolverlaters.

Voor een deel hangt het effect van studievertraging ook samen met verschillen naar sekse, etniciteit, studierichting en de regio. Weliswaar blijft het effect van studievertraging significant positief, maar dit effect daalt flink nadat rekening wordt gehouden met deze kenmerken. Van deze kenmerken is allereerst sekse relevant. Vrouwelijke schoolverlaters behalen gemiddeld genomen een lager beroepsprestige dan hun mannelijke tegenhangers. Daarnaast zijn er aanzienlijke verschillen tussen opleidingsrichtingen. Schoolverlaters met een agrarische opleidingsachtergrond hebben een beroep met gemiddeld het laagste beroepsprestige, gevolgd door schoolverlaters met een verzorgende opleiding. Het beroepsprestige is het hoogst voor degenen die een technische opleidingsrichting hebben gevolgd dan wel een richting die in de restcategorie is ingedeeld. Verder geldt dat schoolverlaters uit de Randstad gemiddeld een hoger beroepsprestige behalen dan schoolverlaters uit de andere regio's van Nederland.

Verschillende cognitieve vaardigheden, soft skills en ouderlijke hulpbronnen zijn van invloed op het beroepsprestige van de baan waarin schoolverlaters werkzaam zijn. In de eerste plaats zijn schoolprestaties van belang. Naarmate schoolverlaters betere prestaties hebben behaald in het voortgezet onderwijs, des te hoger is het prestige van het beroep dat ze uitoefenen.

In de tweede plaats heeft non-verbale intelligentie een effect op het beroepsprestige. Schoolverlaters met een hoog IQ zijn werkzaam in een beroep met een hoger beroepsprestige dan schoolverlaters met een laag IQ. In de derde plaats doet schoolbeleving ertoe. Schoolverlaters die het naar hun zin hebben gehad op school, hebben een baan met een hoger beroepsprestige dan schoolverlaters die met minder plezier naar school zijn gegaan. In de vierde plaats is het opleidingsniveau van de ouders bepalend voor het beroepsprestige van de baan waarin schoolverlaters zijn terechtgekomen. Naarmate de ouders hoger zijn opgeleid, des te hoger is het beroepsprestige van de baan. Ondanks de invloed van deze uiteenlopende kenmerken interpreteren ze nauwelijks de invloed van het aantal jaren scholing (met en zonder diploma) op het beroepsprestige van de gevonden baan. Het gaat dus vooral om additionele effecten naast het bereikte opleidingsniveau. $\mathrm{Na}$ correctie voor deze kenmerken blijft het opleidingsniveau van schoolverlaters sterk bepalend voor het beroepsprestige van de gevonden baan. 
Tabel 4.6

Resultaten van de analyse van het beroepsprestige: ongestandaardiseerde regressiecoëfficiënten $(N=7.719)$

\begin{tabular}{|c|c|c|c|c|}
\hline & Model 1 & Model 2 & Model 3 & Model 4 \\
\hline Intercept & $2,039 * *$ & $1,524^{* *}$ & $-1,255$ & $-8,905$ \\
\hline Opleidingsniveau & $2,779^{* *}$ & $2,868^{* *}$ & $2,463^{\star *}$ & $2,275^{\star *}$ \\
\hline Aanvullende scholing zonder diploma & $2,927^{* \star}$ & $3,140 * *$ & $3,012^{* *}$ & $3,040^{* *}$ \\
\hline Studievertraging & $1,573^{* *}$ & $0,828^{*}$ & $0,874^{*}$ & $0,849^{*}$ \\
\hline \multicolumn{5}{|l|}{ Sekse } \\
\hline Man (ref.) & & - & - & - \\
\hline Vrouw & & $-1,193^{* *}$ & $-1,066^{* *}$ & $-1,178^{* *}$ \\
\hline \multicolumn{5}{|l|}{ Etniciteit } \\
\hline Autochtoon (ref.) & & - & - & - \\
\hline Allochtoon & & $-0,539$ & $-0,022$ & $-0,126$ \\
\hline \multicolumn{5}{|l|}{ Opleidingsrichting } \\
\hline \multicolumn{5}{|l|}{ Algemeen (ref.) } \\
\hline Landbouw & & $-7,922^{* *}$ & $-6,032^{* *}$ & $-5,010^{* *}$ \\
\hline Techniek & & $3,224^{\star *}$ & $4,753^{\star *}$ & $5,833^{\star *}$ \\
\hline Economie & & $-0,569$ & 0,823 & $1,592^{\star *}$ \\
\hline Gezondheidszorg & & $-4,538^{* *}$ & $-2,619^{* *}$ & $-1,560^{*}$ \\
\hline Overig & & $2,587^{* *}$ & $4,084^{* *}$ & $4,946^{* *}$ \\
\hline \multicolumn{5}{|l|}{ Regio } \\
\hline Randstad & & $1,518^{* *}$ & $1,401^{* *}$ & $1,271^{* *}$ \\
\hline Overig (ref.) & & - & - & - \\
\hline Schoolprestaties & & & $4,881^{\star *}$ & $2,427^{* *}$ \\
\hline Non-verbale intelligentie & & & $1,531^{*}$ & 1,227 \\
\hline Prestatiemotivatie & & & 0,139 & 0,219 \\
\hline Schoolbeleving & & & $1,923^{* *}$ & $1,881^{* *}$ \\
\hline Opleidingsniveau ouders & & & $0,163^{*}$ & $0,124^{*}$ \\
\hline \multicolumn{5}{|l|}{ Maatschappelijke positie ouders } \\
\hline Niet werkzaam (ref.) & & & - & - \\
\hline Arbeider & & & $-0,316$ & $-0,179$ \\
\hline Zelfstandige zonder personeel & & & $-0,506$ & $-0,441$ \\
\hline Zelfstandige met personeel & & & $-0,163$ & $-0,141$ \\
\hline Lagere employee & & & $-0,139$ & $-0,118$ \\
\hline Middelbare employee & & & $-0,106$ & $-0,088$ \\
\hline Hogere employee & & & 0,999 & 0,941 \\
\hline Culturele participatie ouders & & & $-0,498$ & $-0,509$ \\
\hline Leesgedrag ouders & & & 0,880 & 0,815 \\
\hline Onderwijsondersteunend thuisklimaat & & & 0,976 & 0,925 \\
\hline Schooladvies & & & & $1,615^{\star *}$ \\
\hline Aangepaste $\mathrm{R}^{2}$ & 0,253 & 0,293 & 0,302 & 0,305 \\
\hline
\end{tabular}

${ }^{* *} p<0,01 ;{ }^{*} p<0,05$

ref. $=$ referentiecategorie

Bron: Schoolverlatersdata VOCL'89, 1994-2003, Centraal Bureau voor de Statistiek

Toevoeging van het schooladvies voor het voortgezet onderwijs verandert het beeld niet. Het schooladvies heeft weliswaar een positief effect op het beroepsprestige, maar desondanks blijft het aantal jaren scholing (met en zonder diploma) erg belangrijk. Alleen bij het aantal jaren bereikte scholing neemt het effect enigszins af: van 2,463 in model 3 naar 2,275 in model 4. 


\subsection{Persoonlijk bruto jaarloon}

In de laatste analyse staat het persoonlijk bruto jaarloon ${ }^{7}$ van schoolverlaters centraal. Zoals mag worden verwacht heeft het behaalde opleidingsniveau een significante invloed op het jaarloon van schoolverlaters. Schoolverlaters met een hoog opleidingsniveau hebben gemiddeld een hoger jaarloon dan schoolverlaters met een lager opleidingsniveau, waarbij één jaar extra scholing leidt tot een gemiddelde stijging van het jaarloon met ongeveer 1.326 euro. Dit effect moet deels worden toegeschreven aan het stelsel van minimum jeugdlonen. Met het stijgen van het opleidingsniveau stijgt ook de leeftijd waarop men op de arbeidsmarkt verschijnt en daarmee het minimum loon. Daarnaast blijkt dat aanvullende scholing zonder diploma ook wordt beloond op de arbeidsmarkt. Schoolverlaters die na het behalen van het diploma nog ten minste één jaar verder zijn gaan leren zonder een diploma te hebben behaald, hebben een hoger jaarloon dan schoolverlaters die direct na afronding van de hoogst behaalde opleiding zijn toegetreden tot de arbeidsmarkt. Enigszins verassend is dat ook schoolverlaters die in de laatst gevolgde opleiding studievertraging hebben opgelopen gemiddeld meer verdienen per jaar dan schoolverlaters die geen vertraging hebben opgelopen. Zowel het positieve effect van aanvullende scholing als het effect van vertraging moet deels verklaard worden als een leeftijdseffect als gevolg van minimum jeugdlonen.

Wanneer rekening wordt gehouden met sekse, etniciteit, gevolgde opleidingsrichting en regio dan wordt de invloed van opleidingsniveau en studievertraging op het jaarloon kleiner, maar zij blijft significant. De invloed van aanvullende scholing zonder diploma op het jaarloon is groter geworden. Daarnaast hebben zowel sekse, etniciteit, de gevolgde opleidingsrichting en regio een significante invloed op het jaarloon van schoolverlaters. Mannen verdienen meer per jaar dan vrouwen en autochtonen verdienen meer per jaar dan allochtonen.

Verder geldt dat schoolverlaters met een algemene opleidingsachtergrond gemiddeld het minst en schoolverlaters van de richting overig het meest verdienen. Schoolverlaters van de richting overig verdienen ongeveer 4.292 euro per jaar meer dan schoolverlaters met een algemene opleidingsachtergrond. ${ }^{8}$ Het jaarloon van schoolverlaters van de richting techniek ligt ongeveer 3.371 euro hoger dan voor schoolverlaters met een algemene opleidingsachtergrond. Voor schoolverlaters van de richtingen landbouw, economie en gezondheidszorg is het jaarloon respectievelijk 3.169 euro, 1.706 euro en 1.500 euro hoger dan voor schoolverlaters met een algemene opleidingsachtergrond. Tot slot laat de tabel zien dat het gemiddelde jaarloon van schoolverlaters uit de Randstad hoger is dan voor schoolverlaters uit andere regio's van Nederland.

7. In deze analyses zijn de WO schoolverlaters buiten beschouwing gelaten omdat er slechts tot en met 2000 looninformatie beschikbaar is. In 2000 zijn er te weinig schoolverlaters met een WO diploma op de arbeidsmarkt gekomen om hierover uitspraken te kunnen doen.

8. Tot de categorie 'overig' behoren onder meer lerarenopleidingen en sociaal-cultureel werk. Het relatief hoge loon in deze opleidingsrichting wordt grotendeels veroorzaakt door het grote aantal HBO-ers met een lerarenopleiding, 
Tabel 4.7

Resultaten van de analyse van het persoonlijk bruto jaarloon: ongestandaardiseerde regressiecoëfficiënten $(\mathrm{N}=2.987)$

\begin{tabular}{|c|c|c|c|c|}
\hline & Model 1 & Model 2 & Model 3 & Model 4 \\
\hline Intercept & $-5.303^{* *}$ & $-4.645^{\star *}$ & $-4.444^{* *}$ & $-7.144^{* *}$ \\
\hline Opleidingsniveau & $1.326^{\star *}$ & $1.182^{* *}$ & $1.143^{* *}$ & $1.091^{* *}$ \\
\hline Aanvullende scholing zonder diploma & $1.594^{* *}$ & $2.185^{\star \star}$ & $2.162^{\star \star}$ & $2.188^{\star \star}$ \\
\hline Studievertraging & $1.162^{* *}$ & $694^{* *}$ & $734^{* *}$ & $715^{\star *}$ \\
\hline \multicolumn{5}{|l|}{ Sekse } \\
\hline Vrouw & & $-1.557^{* *}$ & $-1.600^{* *}$ & $-1.634^{* *}$ \\
\hline \multicolumn{5}{|l|}{ Etniciteit } \\
\hline \multicolumn{5}{|l|}{ Autochtoon (ref.) } \\
\hline Allochtoon & & $-924^{*}$ & $-912^{*}$ & $-969^{\star *}$ \\
\hline \multicolumn{5}{|l|}{ Opleidingsrichting } \\
\hline Landbouw & & $3.169^{\star *}$ & $3.438^{* *}$ & $3.801^{* *}$ \\
\hline Techniek & & $3.371^{* *}$ & $3.480^{\star *}$ & $3.864^{\star *}$ \\
\hline Economie & & $1.706^{\star *}$ & $1.820^{* *}$ & $2.171^{* *}$ \\
\hline Gezondheidszorg & & $1.580^{* *}$ & $1.814^{\star *}$ & $2.087^{* *}$ \\
\hline Overig & & $4.292^{* *}$ & $4.545^{\star \star}$ & $4.797^{* *}$ \\
\hline \multicolumn{5}{|l|}{ Regio } \\
\hline $\begin{array}{l}\text { Randstad } \\
\text { Overig (ref.) }\end{array}$ & & $632^{* *}$ & $621^{* *}$ & $542^{* *}$ \\
\hline Schoolprestaties & & & $947^{*}$ & $142^{*}$ \\
\hline Non-verbale intelligentie & & & 713 & 608 \\
\hline Prestatiemotivatie & & & -318 & -266 \\
\hline Schoolbeleving & & & 574 & 558 \\
\hline Opleidingsniveau ouders & & & -39 & -52 \\
\hline \multicolumn{5}{|l|}{ Maatschappelijke positie ouders } \\
\hline \multicolumn{5}{|l|}{ Niet werkzaam (ref.) } \\
\hline Arbeider & & & -39 & -22 \\
\hline Zelfstandige zonder personeel & & & -138 & -132 \\
\hline Zelfstandige met personeel & & & -190 & -272 \\
\hline Lagere employee & & & 676 & 655 \\
\hline Middelbare employee & & & 304 & 257 \\
\hline Hogere employee & & & -288 & -343 \\
\hline Culturele participatie ouders & & & $-844^{*}$ & $-857^{*}$ \\
\hline Leesgedrag ouders & & & -167 & -218 \\
\hline Onderwijsondersteunend thuisklimaat & & & 137 & 111 \\
\hline Schooladvies & & & & $546^{\star *}$ \\
\hline Aangepaste $\mathrm{R}^{2}$ & 0,244 & 0,306 & 0,308 & 0,310 \\
\hline
\end{tabular}

${ }^{* *} p<0,01 ;{ }^{*} p<0,05$

ref. $=$ referentiecategorie

Bron: Schoolverlatersdata VOCL'89; 1994-2003, Regionaal Inkomens Onderzoek 1995-2000,

Centraal Bureau voor de Statistiek

Daarnaast komt naar voren dat schoolprestaties en culturele hulpbronnen van invloed zijn op het jaarloon. Hierbij geldt dat het jaarloon van schoolverlaters hoger is wanneer ze betere prestaties hebben behaald in het voortgezet onderwijs. Verder blijkt dat de culturele participatie van ouders een negatieve invloed heeft op het jaarloon van schoolverlaters. Schoolverlaters met ouders die vaak het theater, toneel et cetera bezoeken, verdienen significant minder per jaar dan schoolverlaters waarvan de ouders dit minder vaak doen. Wanneer in de analyse rekening wordt gehouden met het schooladvies van schoolverlaters, is de invloed van de schoolprestaties op het jaarloon verdwenen. Schooladvies zelf heeft een significant 
positieve invloed op het jaarloon van schoolverlaters. Dit betekent dat schooladvies zowel direct als indirect (via het behaalde opleidingsniveau) een positieve bijdrage levert aan het jaarloon. 



\section{Samenvatting en conclusies}

In dit rapport zijn de effecten van onderwijs, competenties en sociale en culturele hulpbronnen op de arbeidsmarktloopbaan onderzocht. Eerst is ingegaan op de directe relatie tussen het opleidingsniveau en de opleidingsrichting van schoolverlaters enerzijds en hun arbeidsmarktkansen anderzijds. Het blijkt dat de kansen op de arbeidsmarkt toenemen naarmate men hoger geschoold is. Zo zijn hoog opgeleiden minder vaak werkloos. Het grootste verschil doet zich voor tussen basisonderwijs, VBO en AVO enerzijds en MBO, HBO en WO anderzijds. Dit valt min of meer samen met het onderscheid tussen het wel of niet hebben van een startkwalificatie. Daarnaast blijkt dat hoger opgeleiden meer prestigieuze banen hebben en een hoger loon dan laag geschoolden. Wat betreft de werkzekerheid zijn de verschillen over het algemeen niet groot met uitzondering van het basisonderwijs. Naast het opleidingsniveau zijn er ook verschillen gevonden tussen onderwijssectoren wat betreft de arbeidsmarktkansen van schoolverlaters. Technisch geschoolden blijken doorgaans een betere arbeidsmarktpositie te hebben dan schoolverlaters uit andere sectoren. Alleen voor universitair geschoolden geldt dat degenen met een opleiding in de gezondheidszorg het beter doen op de arbeidsmarkt. Dit is ook wat mag worden verwacht, aangezien medici over het algemeen vrij eenvoudig werk kunnen vinden. Bovendien liggen de salarissen en het beroepsprestige van artsen relatief hoog.

Vervolgens is onderzocht welke kennis en vaardigheden schuil gaan achter de verschillende diploma's. Centraal hierbij staat de vraag in hoeverre het effect van het aantal jaren gevolgd onderwijs op de arbeidsmarktpositie van schoolverlaters kan worden toegeschreven aan kenmerken van leerlingen die aanwezig waren voorafgaand aan de start van de opleiding, zoals cognitieve kenmerken, soft skills en sociale en culturele hulpbronnen. Dit is gedaan door te bekijken in hoeverre deze kenmerken direct en indirect (via het behaalde opleidingsniveau) de arbeidsmarktpositie van schoolverlaters bepalen. Wat betreft de arbeidsmarktpositie van schoolverlaters zijn de kans op (vast) werk, de aansluiting tussen de opleiding en het gevonden werk, het beroepsprestige en de beloning van schoolverlaters onderzocht.

\subsection{Samenvatting}

Vrouwen hebben een succesvoller onderwijsloopbaan dan mannen. Maar mannen bereiken uiteindelijk een betere positie op de arbeidsmarkt dan vrouwen. De verschillen in arbeidsmarktsucces tussen mannen en vrouwen blijven overeind wanneer rekening wordt gehouden met cognitieve kenmerken, soft skills en sociale en culturele hulpbronnen van schoolverlaters.

Wat betreft de onderwijsloopbaan zijn allochtonen duidelijk minder succesvol dan autochtonen. Dit geldt ook voor de arbeidsmarktpositie. Daarbij gaat het vooral om de kans op (vast) werk, de kans op een baan die aansluit bij de gevolgde opleidingsrichting en het loon. Echter de gevonden verschillen tussen allochtone en autochtone schoolverlaters in onderwijssucces kunnen voor een deel worden 
toegeschreven aan verschillen in cognitieve kenmerken, soft skills en sociale en culturele hulpbronnen.

Naast sekse en etniciteit heeft ook de regio waarin de schoolverlater woont invloed op de transitie van opleiding naar werk. Wanneer schoolverlaters in de Randstad wonen hebben ze een grotere kans een baan te vinden die aansluit bij het behaalde opleidingsniveau en een baan met meer prestige en een hoger jaarloon dan schoolverlaters uit andere regio's van Nederland.

Schoolprestaties en non-verbale intelligentie blijken belangrijke factoren te zijn bij het verklaren van het onderwijsniveau. Non-verbale intelligentie heeft echter niet alleen indirect, via het behaalde opleidingsniveau, maar ook direct een positieve invloed op de kans op betaald werk. Er is echter geen directe invloed van schoolprestaties. Verder hebben prestatiemotivatie, los van het behaalde opleidingsniveau, een positieve invloed op het prestige van de baan van schoolverlaters.

De analyses hebben laten zien dat het behaalde opleidingsniveau van schoolverlaters mede wordt bepaald door prestatiemotivatie en schoolbeleving. Deze bleken zelfs belangrijker dan de non-verbale intelligentie. Daarentegen is er geen directe invloed van schoolprestaties en schoolbeleving op de kans op betaald werk. Verder heeft schoolbeleving, los van het behaalde opleidingsniveau, een positieve invloed op het prestige van de baan van schoolverlaters.

Van de sociale en culturele hulpbronnen blijkt het opleidingsniveau van de ouders het meest belangrijk, gevolgd door de maatschappelijke positie, het onderwijsondersteunend klimaat en de culturele participatie. De invloed op de arbeidsmarktpositie van schoolverlaters verloopt vooral indirect, via het behaalde opleidingsniveau, maar ook deels direct. Hierbij worden vooral effecten van de maatschappelijke positie van de ouder, het opleidingsniveau van de ouders en het onderwijsondersteunend gedrag gevonden. Het effect van culturele participatie van de ouders is ambigue. De indirecte effecten (via het bereikte opleidingsniveau) zijn positief, terwijl de directe effecten negatief zijn (althans voor de kans op vast werk en het jaarloon). Dit lijkt samen te hangen met de differentiële richtingkeuze in het hoger onderwijs, waar de kinderen uit sterk cultureel georiënteerde milieus vaker kiezen voor de cultureel georiënteerde opleidingen met zwakkere arbeidsmarktperspectieven.

Van alle onderscheiden kenmerken in onze analyses heeft het schooladvies de grootste invloed op het uiteindelijk behaalde opleidingsniveau. Het schooladvies blijkt ook een belangrijke voorspeller te zijn van arbeidsmarktsucces. Zelfs wanneer gecontroleerd wordt voor intelligentie en schoolprestaties blijft er een effect van schooladvies bestaan. Schooladvies heeft ook een positieve invloed op het jaarloon van schoolverlaters. Dat betekent dat ook na controle voor het bereikte eindniveau er nog effecten zijn van het niveau zoals al aanwezig bij de overgang van LO naar VO. Scholieren die in vergelijking met het advies een te laag eindniveau behalen worden alsnog gecompenseerd (en omgekeerd natuurlijk). Weinig kenmerken hebben een directe invloed op de kans een baan te vinden die qua niveau of richting aansluit bij 
de gevolgde opleiding. Alleen schooladvies heeft een negatieve invloed op de kans een baan te vinden die aansluit bij de gevolgde opleidingsrichting. Hiervoor is geen duidelijke verklaring gevonden.

Het is gebleken dat een aanzienlijk deel van de effecten van schoolprestaties, nonverbale intelligentie en het opleidingsniveau van de ouders verdwijnt wanneer rekening wordt gehouden met het advies dat is gegeven in groep 8. Schooladvies is gebaseerd op de prestaties van de leerling in het basisonderwijs, de score op de CITO eindtoets en de inschatting van de docent(e) over de capaciteiten van de leerling ten aanzien van het vervolgonderwijs. $\mathrm{Er}$ is dus ten dele sprake van een overlap tussen het advies enerzijds en de cognitieve competenties en ouderlijke hulpbronnen anderzijds. Het is dan ook niet vreemd dat de invloed van schoolprestaties, non-verbale intelligentie en opleidingsniveau van de ouders op arbeidsmarktkenmerken groter is wanneer er géén rekening wordt gehouden met schooladvies.

\subsection{Conclusies}

Een van de doelstellingen van dit onderzoek is het verwerven van kennis over de indicatoren die relevant zijn bij het onderzoek naar de transitie van het onderwijs naar de arbeidsmarkt. Bij de start van dit onderzoek is groot aantal arbeidsmarkt- en schoolloopbaanindicatoren ontwikkeld. Deze indicatoren staan allen beschreven in het indicatorenrapport (CBS, 2004). Na het ontwikkelen van de mogelijk relevante indicatoren is een selectie gemaakt van indicatoren die voor dit onderzoek ook daadwerkelijk van waarde waren. Voor het overgrote deel is de uiteindelijke selectie van arbeidsmarktkenmerken gemaakt op basis van eerder onderzoek en de expertise van het ROA. Uit de analyses blijkt echter wel dat sommige arbeidsmarktkenmerken minder sterk bepaald worden door het opleidingsniveau dan andere.

Vooralsnog lijken de meest zinvolle en onderscheidende arbeidsmarktkenmerken in ieder geval de kans op werk, de kans op een baan op niveau en het inkomen te zijn. De kans op vast werk is veel minder onderscheidend, evenals de kans op een baan in de richting. Het beroepsprestige lijkt qua resultaten niet erg veel af te wijken van het inkomen als indicator voor arbeidsmarktsucces. In gevallen waar geen meting van inkomen beschikbaar is, zou het wel als een goed alternatief kunnen dienen. Alvorens we echter een definitieve selectie maken van relevante indicatoren voor arbeidsmarktsucces is het verstandig een gelijksoortige analyse uit te voeren op een ander cohort of op een geheel andere dataset om na te gaan in hoeverre de hier gevonden resultaten ook stabiel blijken te zijn over de tijd.

Naast het selecteren van relevante kenmerken van de arbeidsmarktloopbaan is het ook van belang een goed onderscheid te maken naar meer en minder relevante kenmerken van de onderwijsloopbaan bij het analyseren van de transitie van het onderwijs naar de arbeidsmarkt. In eerste instantie is een groot aantal kenmerken van de onderwijsloopbaan geoperationaliseerd. Deze staan allen beschreven in het indicatorenrapport (CBS, 2004). In de uiteindelijke analyses is hiervan, naast natuurlijk het niveau en de richting van de hoogst behaalde opleiding, alleen het 
doubleren gedurende de laatste opleiding en het hebben van aanvullende scholing zonder diploma opgenomen in de modellen. Deze kenmerken bleken allemaal een belangrijke bijdrage te leveren in de verklaringsmodellen. Ook hier is de keuze gebaseerd op eerdere analyses en expertise. Het zijn de meest gangbare indicatoren van de schoolloopbaan in het onderzoek naar de overgang van onderwijs naar de arbeidsmarkt.

Naast het verwerven van inzicht in relevante indicatoren in het proces van de transitie van onderwijs naar arbeidsmarkt hebben we ook getracht het proces zelf zo goed mogelijk te beschrijven en te ontrafelen. Een van de instrumenten hierbij was het aanvullen van CBS-data met de schoolverlatersdata van het ROA (SIS) om zo leeftijds-, periode- en cohorteffecten te onderscheiden. De schoolverlatersdata van het VOCL'89 bleken hiervoor echter niet voldoende spreiding te bevatten in de uitstroommomenten uit de verschillende onderwijsniveaus (zie bijlage 2). Het is echter zeer goed mogelijk dat een combinatie van het VOCL'89 met het VOCL'93 wel voldoende diversiteit in uitstroom zou opleveren. Dit zou in een vervolgonderzoek verder moeten worden uitgezocht. Voor toekomstig onderzoek naar de dynamiek van schoolverlaters is het om deze reden wenselijk jaarlijks een nieuw cohort te starten. Met de komst van het leerlingnummer en de integrale tellingen in zowel het voortgezet onderwijs, het middelbare beroepsonderwijs, als het hoger onderwijs zal het betrekkelijk eenvoudig zijn cohortinformatie over de onderwijsloopbaan te verzamelen. Of ook de arbeidsmarktinformatie vanuit registraties zal kunnen worden verzameld zal uit het tweede deelproject moeten blijken. Dit start in het najaar van 2004.

In dit onderzoek is uitsluitend nagegaan hoe de transitie van het onderwijs naar de arbeidsmarkt verloopt op korte termijn. In alle gevallen is het arbeidsmarktsucces anderhalf jaar na de uitstroom uit het onderwijs bekeken. Over de lange termijn effecten is echter nog altijd weinig bekend. In het najaar van 2004 zal daarom van start gegaan worden met een vervolgstudie waarin de huidige arbeidsmarktsituatie van oudere cohorten zal worden nagegaan. In tegenstelling tot de huidige data, die via vragenlijsten is verzameld, zullen we in dat project gebruik gaan maken van data die verkregen zijn uit registraties. Het CBS beschikt sinds enkele jaren over een groot aantal registraties op allerlei terreinen, welke zijn samengevoegd in een grote database: het Sociaal Statistisch Bestand (SSB). In dit SSB is bijvoorbeeld informatie te vinden over uitkeringsgerechtigden en inkomstenbelasting. Door een koppeling te maken tussen bijvoorbeeld het SMVO en het SSB kan inzicht worden verkregen in de arbeidsmarktsituatie van personen die nu ongeveer 34 jaar zijn. Hierdoor is het mogelijk ook de lange termijn opbrengsten van het onderwijs beter in kaart te brengen. 


\section{Bijlage 1 Populatie}

Het uitgangspunt voor de populatie schoolverlaters wordt gevormd door de 19.524 leerlingen in het Voortgezet Onderwijs Cohort Leerlingen 1989. Jaarlijks worden de leerlingen die uit het regulier voltijd dagonderwijs vertrekken benaderd met een schoolverlatersvragenlijst. Op 1 september 2003 verbleven nog 580 leerlingen in het regulier voltijd dagonderwijs. Leerlingen die uitstromen wegens ziekte, overlijden, verhuizing naar het buitenland of omdat ze weigeren nog langer aan het onderzoek deel te nemen worden niet opgenomen in de schoolverlatersenquêtering. Het gaat in totaal om 1.897 leerlingen. In totaal zijn dus 17.047 leerlingen opgenomen in het schoolverlatersonderzoek. Hiervan hebben er $2.963(17 \%)$ niet gerespondeerd. Daarnaast zijn er 1.145 leerlingen die gedurende het interview toch weer volledig dagonderwijs bleken te volgen. Deze leerlingen zijn ten behoeve van deze analyses verwijderd uit de onderzoekspopulatie.

Tabel 1

Afbakening populatie in de analyse

Totaal aantal leerlingen in VOCL ' 89

Leerlingen die per 01-09-2003 nog onderwijs volgden

Schoolverlaters die niet voor het schoolverlatersdeel in aanmerking zijn gekomen (overleden, ziek, buitenland etc.)

Schoolverlaters die bij nader inzien toch nog voltijd onderwijs bleken te volgen

Bron: Schoolverlatersdata VOCL'89, 1994-2003, Centraal Bureau voor de Statistiek

Om te achterhalen of de onderzoeksresultaten die gebaseerd zijn op de gegevens van deze responsgroep geen vertekening van de werkelijkheid vormen, is het van belang na te gaan of er sprake is van een selectieve (non-) respons. Het mag niet zo zijn dat de groep respondenten en de groep non-respondenten op kenmerken van elkaar verschillen. Onder meer is gekeken naar de verdelingen van geslacht, leeftijd etniciteit, sociale herkomt en hoogst behaald onderwijsniveau over de responsgroep en de non-responsgroep. Hierbij zijn geen aanwijzingen gevonden voor selectiviteit. 



\section{Bijlage 2 Het corrigeren van leeftijd-, periode- en cohorteffecten}

Het is goed om op te merken dat panel- en cross-sectionele designs verschillende conclusies kunnen opleveren (Rijken \& Dronkers, 2001). Dit komt omdat panelonderzoek en crossecties verschillen wat betreft hun omvang, de tijdsperiode die ze beslaan en de mate van gedetailleerdheid van de informatie die wordt verzameld. Met behulp van cross-sectionele surveys kunnen een groot aantal personen over een groot aantal onderwerpen op één moment worden ondervraagd. De gedetailleerdheid van de verzamelde informatie van crossecties is echter minder groot dan van paneldata. Bij paneldata worden dezelfde personen op verschillende tijdstippen benaderd, waardoor paneldata vaak uitgebreide informatie bevatten over de schoolloopbaan. Wel geldt dat paneldata sterk afhankelijk zijn van de bereidheid van respondenten om mee te blijven werken.

Alhoewel het cohortdesign vele voordelen biedt boven een cross-sectionele onderzoeksopzet kleeft er één groot probleem aan deze wijze van dataverzameling. Onherroepelijk zal men aan lopen tegen het punt dat het ontrafelen van leeftijd-, periode- en cohorteffecten moeizaam is. De oorzaak hiervan is dat leeftijd, periode en cohort geen onafhankelijke grootheden zijn. Stel bijvoorbeeld dat zowel het geboortejaar als de periode (het interviewmoment) bekend zijn; de leeftijd is hieruit dan eenvoudig af te leiden. Wanneer men in een analyse dan deze grootheden simultaan wil schatten, dan levert dit een collineariteitsprobleem op.

Ook in dit onderzoek speelt dit probleem een rol. Omdat het hier een cohort van brugklasleerlingen betreft hangt het uitstroomjaar sterk samen met het opleidingsniveau van de schoolverlater; hoe hoger het opleidingsniveau, des te later ligt het uitstroommoment. Dit is geïllustreerd in tabel 2.1. Uit deze tabel kan men bijvoorbeeld stellen dat wanneer een schoolverlater in 1994 van school is gekomen men met $60 \%$ zekerheid kan zeggen dat het om een VBO-er gaat. Om uitspraken te kunnen doen over verschillen tussen opleidingen willen we kunnen controleren voor het uitstroommoment omdat het jaar waarin men van school komt iets zegt over de economische omstandigheden waaronder men een baan zoekt. Ten tijde van economische malaise is het immers moeilijker een baan te vinden dan in tijden van hoogconjunctuur. Wanneer men echter in het model controleert voor economische toestand, bijvoorbeeld door het werkloosheidspercentage per jaar op te nemen, dan levert dit wederom een collineaire set variabelen op. Aan de hand van het uitstroomjaar kan namelijk met een vrij grote zekerheid worden voorspeld welk opleidingsniveau een schoolverlater in dat jaar had. Wanneer andersom het werkloosheidspercentage in een bepaald jaar gegeven is, dan is ook met een bepaalde zekerheid bekend welk opleidingsniveau een schoolverlater had die onder die economische condities op de arbeidsmarkt kwam. Wanneer bijvoorbeeld de kans op het hebben van een baan op niveau wordt geschat voor de verschillende opleidingsniveaus, en zowel het opleidingsniveau als het werkloosheidspercentage in de verschillende uitstroomjaren worden in het model opgenomen, dan zal het effect 
van opleiding vrijwel geheel worden weg verklaard door de economische toestand. In het oorspronkelijke onderzoeksplan was voorgesteld dit te corrigeren op basis van de cross-sectionele SIS-data van het ROA. Per arbeidsmarktindicator zou uit een vergelijkbare populatie uit het SIS per opleiding en per jaar een correctiefactor worden berekend. Deze methode is uitgeprobeerd in de analyses maar bleek niet voldoende te corrigeren vanwege de te beperkte spreiding van schoolverlaters met verschillende opleidingsniveaus over de onderzoeksjaren. Deze methode is dus niet toe te passen.

De problematiek van het scheiden van leeftijd-, periode- en cohorteffecten is al door meerdere onderzoekers aan de orde gesteld en er zijn ook meerdere oplossingen voor gesuggereerd (zie voor een overzicht Te Grotenhuis et al., 1998). Een eerste mogelijkheid is de theoretische aanname te maken dat één van de drie effecten niet bestaat en deze vervolgens buiten beschouwing te laten. Als ernstig nadeel hiervan stellen Te Grotenhuis et al. dat men geen empirische argumenten kan geven voor het weglaten van een variabele in het model. De hypothesen kunnen dan niet meer empirisch worden getoetst.

Een tweede oplossing is het vergaand samenvoegen van categorieën, waardoor de predictoren minder afhankelijk van elkaar worden. Ook hiertegen zijn echter ernstige bewaren op te werpen. Het grootste nadeel is dat de wijze van categoriseren van grote invloed is op de conclusies. Tenzij men theoretische gronden heeft voor een bepaalde categorisering zijn de conclusies gebaseerd op een zekere willekeur. Overigens is deze oplossing in onze analyses wel getest door voor het werkloosheidspercentage een driedeling te maken in laag,- middel,- en hoogconjunctuur. Hoewel de correlatie tussen deze nieuwe correctiefactor en het opleidingsniveau hiermee wel iets verminderde bleek er nog steeds sprake van collineariteit. Deze oplossing is dan ook verworpen.

De derde oplossing die Te Grotenhuis et al. bespreken is het zo min mogelijk categoriseren van predictoren met als doel zo min mogelijk informatie te verliezen en een zo groot mogelijke variantie te creëren. Ook deze oplossing is niet probleemloos, vooral omdat de conclusies wederom sterk afhankelijk zijn van de gemaakte keuzes bij het categoriseren. Bovendien blijkt ook deze oplossing het punt van collineariteit niet aan te pakken. Ook dit wordt dus niet gezien als een oplossing.

Vanwege bovenstaande redenen is in deze analyses afgezien van een correctie voor conjunctureel klimaat. In vervolgonderzoek zal geprobeerd worden dit probleem te ondervangen door meerdere cohorten tegelijkertijd te analyseren. 


\section{Bijlage 3 Operationalisering van de variabelen}

In deze bijlage wordt per variabele besproken hoe de variabelen die in dit rapport gebruikt zijn, zijn geoperationaliseerd. Voor een uitgebreide beschrijving van de toegepaste definities en het vergelijkbaar maken van de CBS-data met de data van het ROA verwijzen we naar het indicatorenrapport (CBS, 2004).

- Het hoogst bereikte opleidingsniveau van schoolverlaters is gemeten aan de hand van het aantal benodigde jaren scholing om dit niveau te bereiken. Uitgangspunt voor deze berekening is de leerweg die loopt via de beroepsopleidingen (Van der Velden \& van Smoorenburg, 1999). De volgende waarden zijn toegekend: 6 jaren (BO), 10 jaren (LBO), 11 jaren (MAVO), 12 jaren (KMBO), 13 jaren (HAVO), 14 jaren (MBO), 15 jaren (VWO), 17 jaren (HBO) en 19 jaren (WO). Daarnaast is een variabele onderscheiden die aangeeft of schoolverlaters na het hoogst bereikte opleidingsniveau nog een andere opleiding in het initiële onderwijs hebben gevolgd (voor ten minste twee jaren), maar deze niet hebben afgemaakt. Tevens is een variabele aangemaakt die weergeeft of men tijdens de hoogst bereikte opleiding (minimaal een keer) een jaar vertraging heeft opgelopen. De opleidingsrichting van het hoogst bereikte opleidingsniveau tot slot is ingedeeld in zes categorieën, te weten: 1) algemeen, 2) landbouw, 3) techniek, 4) economie 5) gezondheidszorg en 6) overig. We rekenen iedereen die basisonderwijs, MAVO, HAVO of VWO als hoogst behaalde opleiding hebben behaald tot de categorie 'algemeen'.

- Een allochtoon is ofwel iemand die in het buitenland is geboren of iemand van wie een van beide ouders in het buitenland is geboren. Landen die als buitenland worden aangemerkt, staan vermeld in de Wet Stimulering Arbeidsdeelname Minderheden (SAMEN).

- Schoolprestaties zijn gebaseerd op de totaalscore op drie toetsen (Nederlands, rekenen en informatieverwerking), die met behulp van een door het CITO samengestelde versie van de Entreetoets halverwege het eerste schooljaar zijn afgenomen. De toetsen omvatten ieder 20 multiple choice-vragen. Cronbach's alpha van de drie toetsen bedragen respectievelijk 0,76, 0,84 en 0,77. De totaalscore is uitgedrukt op een schaal lopend van 0 tot en met 1.

- Non-verbale intelligentie is vastgesteld door een tweetal toetsen, die beiden halverwege het eerste leerjaar zijn afgenomen. De eerste subtest (PSB-3) meet het redeneervermogen; de tweede subtest (PSB-8) het abstractievermogen. Beide subtesten bestaan uit 40 items. Cronbach's alpha is 0,82 , respectievelijk 0,90 . Van beide subtesten is het aantal correcte items gesommeerd. Deze somscore is vervolgens getransformeerd naar een schaal met een minimale waarde van 0 en een maximale waarde van 1. 
- Prestatiemotivatie is gemeten aan de hand van de volgende twee uitspraken die aan de leerlingen zijn voorgelegd: 'ik maak mijn schoolwerk graag goed, ook als dat me moeite kost' en 'ik doe weinig mijn best op school'. Van beide items is het gemiddelde genomen. Cronbach's alpha bedraagt 0,45 . De somscore is vervolgens getransformeerd naar een schaal met een bereik tussen 0 en 1 . De meting van prestatiemotivatie heeft plaatsgevonden middels de leerlingvragenlijst die bij de leerlingen is afgenomen in het eerste leerjaar.

- De schoolbeleving van leerlingen is gebaseerd op een schaal bestaande uit 11 items. Cronbach's alpha van deze schaal is 0,75 . De scores op deze schaal lopen tussen 0 en 1 . De meting van schoolbeleving heeft plaatsgevonden middels de leerlingvragenlijst die bij de leerlingen is afgenomen in het eerste leerjaar.

- Het schooladvies is gebaseerd op het advies dat de leerling van de basisschool heeft gekregen met betrekking tot de doorstroom naar het voortgezet onderwijs. Dit advies bestaat uit acht opleidingscategorieën, variërend van IBO tot en met VWO. Deze zijn gecodeerd volgens de leerjarenladder: $I B O=5, V B O=6$, $M A V O=7, H A V O=8, V W O=9$. Leerlingen met een gemengd advies hebben een gemiddelde waarde gekregen.

- De sociale herkomst van de leerlingen is bepaald aan de hand van twee indicatoren, te weten het opleidingsniveau van de ouders en de maatschappelijke positie van de ouders. Deze zijn verzameld via de oudervragenlijst die in het eerste leerjaar bij de ouders is afgenomen. Het bepalen van het opleidingsniveau van de ouders heeft plaatsgevonden op basis van de niveauindeling van de Standaard Onderwijsindeling 1978 (SOI'78) (CBS, 1987). Daarbij is uitgegaan van het gemiddelde opleidingsniveau van (een van) beide ouders. De verschillende niveaus zijn vervolgens omgerekend naar het gemiddelde aantal jaren nominale scholing. Dit levert de volgende waarden op: 6 jaren (lager onderwijs), 10 jaren (voortgezet onderwijs, lager trap), 14 jaren (voortgezet onderwijs, hogere trap), 17 jaren (hoger onderwijs, eerste fase) en 19 jaren (hoger onderwijs, tweede fase). De maatschappelijke positie van de ouders is gebaseerd op informatie over de werkzaamheid en het beroep van de hoofdkostwinner van het gezin. De volgende categorieën zijn onderscheiden: 1) niet werkzaam, 2) arbeider, 3), zelfstandige zonder personeel, 4) zelfstandige met personeel, 5) lagere employee, 6) middelbare employee en 7) hogere employee.

- De culturele hulpbronnen van de ouders zijn gemeten aan de hand van hun culturele participatie en leesgedrag. Ook deze kenmerken zijn verzameld via de oudervragenlijst in het eerste leerjaar. De items behorende bij de schaal voor culturele participatie hebben betrekking op de mate van concert-, toneel- en museumbezoek van beide ouders. Cronbach's alpha van deze schaal bedraagt 0,88 . De items behorende bij de schaal voor leesgedrag hebben betrekking op het aantal gelezen boeken per maand. Cronbach's alpha bedraagt hier 0,40. De 
scores op beide schalen zijn zo getransformeerd dat zij een bereik hebben tussen de waarde 0 en 1.

- Het onderwijsondersteunend thuisklimaat is gebaseerd op vragen aan beide ouders over het hebben van gesprekken over school, het hebben van gesprekken over prestaties en het geven van complimenten over schoolprestaties. Deze vragen zijn gesteld in de oudervragenlijst in het eerste leerjaar. Deze items zijn samengevoegd tot een schaal met een Cronbach's alpha van 0,81 . De minimale waarde van deze schaal is 0 ; de maximale 1.

- $\quad$ Tot de beroepsbevolking worden gerekend: 1) schoolverlaters die ten minste 12 uur per week werken, 2) schoolverlaters die werk hebben aanvaard waardoor ze ten minste 12 uur per week gaan werken of 3) schoolverlaters die verklaren ten minste 12 uur per week willen werken, daarvoor beschikbaar zijn en activiteiten ontplooien om werk voor ten minste 12 uur per week te vinden. Van de beroepsbevolking worden schoolverlaters die ten minste 12 uur per week werken tot de werkzame beroepsbevolking gerekend en degenen die niet of minder dan 12 uur werken tot de werkloze beroepsbevolking. De variabelen die nodig zijn voor het bepalen van de beroepsbevolking zijn afkomstig uit de SVDvragenlijst die is afgenomen ongeveer anderhalf jaar na schoolverlaten.

- Schoolverlaters hebben vast werk als zij aangeven 1) dat zij (deels) in vaste dienst zijn, 2) wanneer afgesproken is dat zij bij goed functioneren in vaste dienst komen of 3 ) als zij een contract hebben van een jaar of langer. Dit kenmerk is afkomstig uit de SVD-vragenlijst die is afgenomen ongeveer anderhalf jaar na schoolverlaten.

- Schoolverlaters hebben een baan op niveau als zij een baan hebben gevonden op hetzelfde niveau als de opleiding die is afgerond. Daarbij is een vergelijking gemaakt tussen de eerste digit van de Standaard Beroepenclassificatie 1992 (SBC'92) (CBS, 1993) en de eerste digit van de SOI 1978. Schoolverlaters hebben een baan in de eigen richting als zij een baan hebben gevonden in dezelfde richting als de opleiding die is afgerond. Hierbij is eveneens een vergelijking gemaakt tussen de SBC'92 en SOI'78. De beroepenclassificatie is ongeveer anderhalf jaar na het verlaten van het voltijd onderwijs bepaald.

- Het beroepsprestige van de baan waarin schoolverlaters werkzaam zijn, is vastgesteld door prestigescores toe te kennen aan beroepsomschrijvingen volgens een schaal die door Ultee en Sixma (Sixma \& Ultee, 1984) is ontwikkeld voor Nederland. Deze schaal varieert van 13 punten (voor beroepen met het minste aanzien) tot en met 87 punten (voor beroepen met het hoogste aanzien). Evenals het beroep is het beroepsprestige ongeveer anderhalf jaar na het schoolverlaten bepaald.

- De beloning van schoolverlaters is gebaseerd op het totale genoten persoonlijk bruto jaarloon. Deze informatie is afkomstig uit het Regionaal Inkomens- 
onderzoek (RIO) en vervolgens via het Sociaal Statistisch Bestand (SSB) (beide van het CBS) gekoppeld aan het VOCL'89. Het RIO is een steekproefonderzoek met een dekking van ongeveer $30 \%$. Daardoor kon niet voor alle respondenten van het VOCL'89 het jaarloon achterhaald worden. Bovendien zijn alleen de loongegevens voor de jaren 1995 tot en met 2000 koppelbaar via Sociaal Statistisch Bestand. Dit betekent dat voor zo'n 30 procent van de schoolverlaters het loon bekend is. Het loon is vervolgens geïndexeerd aan de hand van de Consumenten Prijs Index (CPI) van het CBS zodanig dat alle lonen zijn uitgedrukt in prijzen van 1995.

- De regio waar iemand woont is bepaald aan de hand van het adres waar de schoolverlater woonde op het moment van enquête (circa anderhalf jaar na het verlaten van het onderwijs). De regio is ingedeeld in twee categorieën, de Randstad en overig. Tot de Randstad zijn gerekend de provincies NoordHolland, Zuid-Holland en Utrecht. 


\section{Literatuur}

Becker, G. (1964), Human capital. A theoretical and empirical analysis, with special reference to education. New York: National Bureau of Economic Research.

Bills, D. (2003), Credentials, signals and screens: Explaining the relationship between schooling and job assignment. Review of Educational Research, 73, 441-470.

Bourdieu, P. (1973), Cultural reproduction and social reproduction. In: R. Brown (red.), Knowledge, education and social change (pp. 71-112), London: Tavistock.

CBS (1987), Standaard Onderwijsindeling 1978. Den Haag: Centraal Bureau voor de Statistiek.

CBS (1991), Schoolloopbaan en achtergrond van leerlingen: cohort 1989. Deel 1: instroom. Den Haag: Centraal Bureau voor de Statistiek.

CBS (1993), Standaard Beroepenclassificatie 1992. Den Haag: Centraal Bureau voor de Statistiek.

CBS (2004), De transitie van school naar werk. Indicatoren voor arbeidsmarkt-, onderwijs- en achtergrondkenmerken. Den Haag: Centraal Bureau voor de Statistiek.

Collins, R. (1979), The credential society. A historical sociology of education and stratification. New York: Academic Press.

Driessen, G. \& Werf, G. van der (1992), Het functioneren van het voortgezet onderwijs. Beschrijving steekproef en psychometrische kwaliteit instrumenten. Groningen/Nijmegen: RION/ITS.

Dronkers, J. (1998), Het Trouw-rapportcijfer van scholen in het voortgezet onderwijs: een analyse van de inspectiegegevens over de schooljaren 1995-96 en 1996-97, Tijdschrift voor Onderwijsresearch, 23 (2), 159-175.

Dronkers, J. \& Ultee, W.C. (red.) (1995), Verschuivende ongelijkheid in Nederland. Assen: Van Gorcum.

Grotenhuis, M. te, Lammers, J., Pelzer, B. \& Scheepers, P. (1998), De (on)mogelijkheden om het leeftijds,- periode- en cohorteffect te bepalen: een evaluatie aan de hand van het kerkbezoek in Nederland tussen 1970 en 1995. Sociologische Gids 45, 8-28.

Hannan, D. \& Werquin, P. (1999), Education and labour market change: the dynamics of education to work transitions in Europe, paper presented at the European Socio-Economic Research Conference, Brussels, 28-30 April 1999.

Kerckhoff, A., Raudenbush, S. \& Glennie, E. (2001), Education, cognitive skills and labor force outcomes. Sociology of Education, 74, 1-24.

OECD (1998), Education at a Glance, OECD indicators, Paris: OECD.

Researchcentrum voor Onderwijs en Arbeidsmarkt (2003), Schoolverlaters tussen onderwijs en arbeidsmarkt 2002. Maastricht: ROA.

Researchcentrum voor Onderwijs en Arbeidsmarkt (2002), Schoolverlaters tussen onderwijs en arbeidsmarkt 2001. Maastricht: ROA.

Researchcentrum voor Onderwijs en Arbeidsmarkt (1999), Schoolverlaters tussen onderwijs en arbeidsmarkt 1998. Maastricht: Researchcentrum voor Onderwijs en Arbeidsmarkt. 
Rijken, S. \& Dronkers, J. (2000), Schijn of werkelijkheid? Verschillen tussen trends in onderwijsongelijkheid in paneldata en cross-sectionele data. (nog niet gepubliceerd).

Ryan, P. and Büchtemann, C.F. (1996), The school-to-work transition, In: G.Schmid, J. O'Reilly and K. Schömann (eds), International Handbook of Labour Market Policy and Policy Evaluation, Cheltenham: Edward Elgar.

Sixma, H. \& Ultee, W. (1984), An occupational prestige scale for the Netherlands in the eighties. In: B. Bakker, J. Dronkers \& H. Ganzeboom (red.), Social stratification and mobility in the Netherlands (pp. 29-39). Amsterdam: SISWO.

Spence, M. (1973), Job market signalling. Quarterly Journal of Economics, 87, 355374.

Thurow, L. (1975), Generating inequality. New York: Basic Books.

Velden, R. van der \& Smoorenburg, M. van (1999), Overscholing en beloning. Het effect van verschillende meetmethoden. Tijdschrift voor Arbeidsvraagstukken, 15, 111-123.

Velden, R.K.W. van der (2001), The proof of the pudding is in the eating, Een heuristisch kader voor de kwaliteitsbeoordeling van scholen, In: A.B. Dijkstra et al. (red.), Het oog der natie: scholen op rapport, Assen: Van Gorcum. 